BMC

Physiology

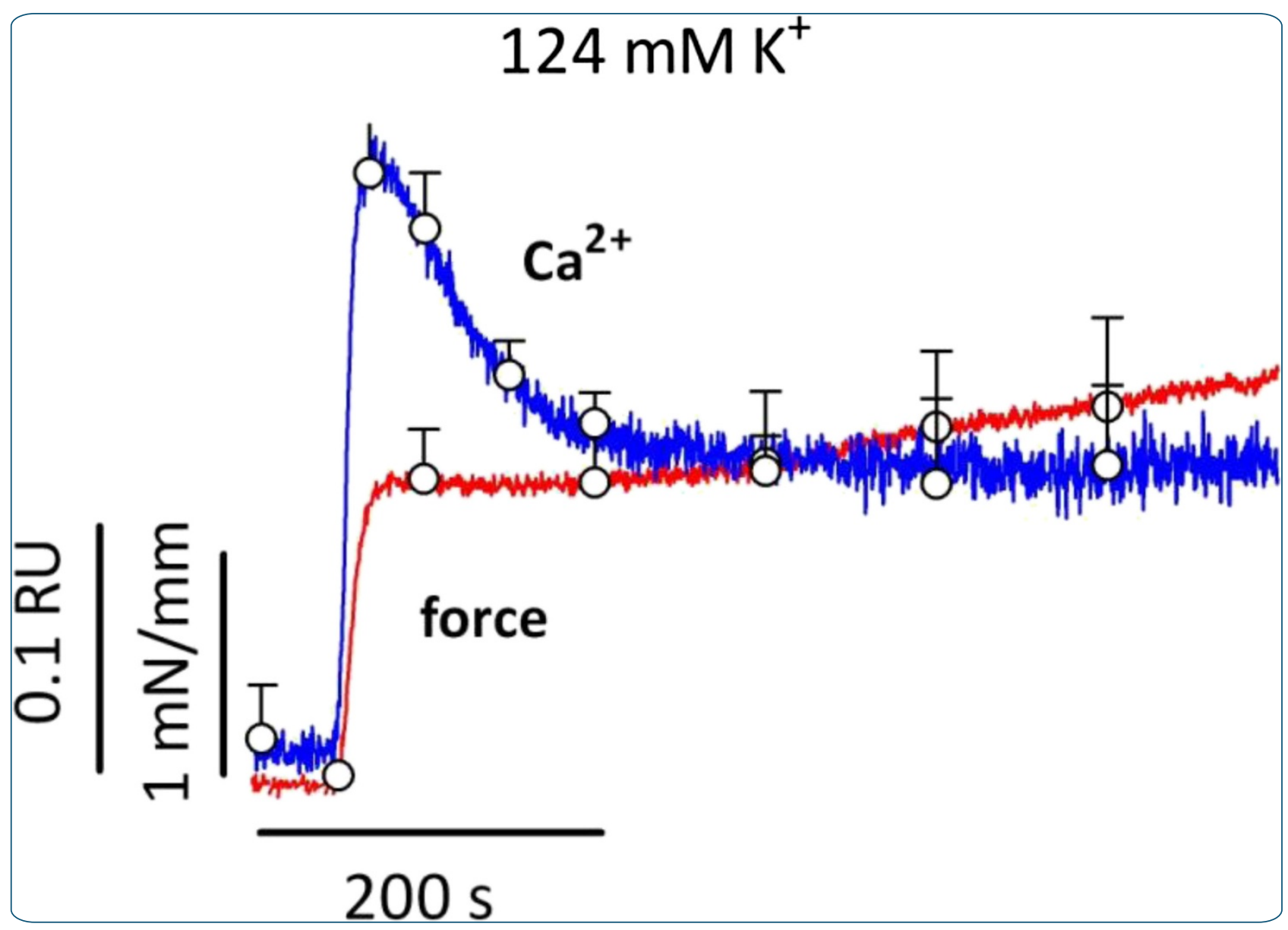

Contribution of transient and sustained calcium influx, and sensitization to depolarization-induced contractions of the intact mouse aorta

Fransen et al.

C Biomed Central 


\title{
Contribution of transient and sustained calcium influx, and sensitization to depolarization-induced contractions of the intact mouse aorta
}

Paul Fransen ${ }^{1 *}$, Cor E Van Hove ${ }^{2}$, Johanna van Langen ${ }^{2}$, Dorien M Schrijvers ${ }^{1}$, Wim Martinet ${ }^{1}$, Guido R Y De Meyer ${ }^{1}$ and Hidde Bult ${ }^{2}$

\begin{abstract}
Background: Electrophysiological studies of L-type $\mathrm{Ca}^{2+}$ channels in isolated vascular smooth muscle cells revealed that depolarization of these cells evoked a transient and a time-independent $\mathrm{Ca}^{2+}$ current. The sustained, non-inactivating current occurred at voltages where voltage-dependent activation and inactivation overlapped (voltage window) and its contribution to basal tone or active tension in larger multicellular blood vessel preparations is unknown at present. This study investigated whether window $\mathrm{Ca}^{2+}$ influx affects isometric contraction of multicellular C57B16 mouse aortic segments.

Results: Intracellular $\mathrm{Ca}^{2+}\left(\mathrm{Ca}_{i}^{2+}\right.$, Fura-2), membrane potential and isometric force were measured in aortic segments, which were clamped at fixed membrane potentials by increasing extracellular $\mathrm{K}^{+}$concentrations. $\mathrm{K}^{+}$above $20 \mathrm{mM}$ evoked biphasic contractions, which were not affected by inhibition of $\mathrm{IP}_{3}-$ or $\mathrm{Ca}^{2+}$ induced $\mathrm{Ca}^{2+}$ release with 2-aminoethoxydiphenyl borate or ryanodine, respectively, ruling out the contribution of intracellular $\mathrm{Ca}^{2+}$ release. The fast force component paralleled $\mathrm{Ca}_{i}^{2+}$ increase, but the slow contraction coincided with $\mathrm{Ca}_{i}^{2+}$ decrease. In the absence of extracellular $\mathrm{Ca}^{2+}$, basal tension and $\mathrm{Ca}_{i}^{2+}$ declined, and depolarization failed to evoke $\mathrm{Ca}_{i}^{2+}$ signals or contraction. Subsequent re-introduction of external $\mathrm{Ca}^{2+}$ elicited only slow contractions, which were now matched by $\mathrm{Ca}_{i}^{2+}$ increase. After $\mathrm{Ca}_{i}^{2+}$ attained steady-state, isometric force kept increasing due to $\mathrm{Ca}^{2+}$ - sensitization of the contractile elements. The slow force responses displayed a bell-shaped voltage-dependence, were suppressed by hyperpolarization with levcromakalim, and enhanced by an agonist of L-type $\mathrm{Ca}^{2+}$ channels (BAY K8644).
\end{abstract}

Conclusion: The isometric response of mouse aortic segments to depolarization consists of a fast, transient contraction paralleled by a transient $\mathrm{Ca}^{2+}$ influx via $\mathrm{Ca}^{2+}$ channels which completely inactivate. $\mathrm{Ca}^{2+}$ channels, which did not completely inactivate during the depolarization, initiated a second, sustained phase of contraction, which was matched by a sustained non-inactivating window $\mathrm{Ca}^{2+}$ influx. Together with sensitization, this window L-type $\mathrm{Ca}^{2+}$ influx is a major determinant of basal and active tension of mouse aortic smooth muscle.

Keywords: Vascular smooth muscle, L-type $\mathrm{Ca}^{2+}$ channel, Vasoconstriction, Intracellular $\mathrm{Ca}^{2+}$, Depolarization, Window $\mathrm{Ca}^{2+}$ influx

\footnotetext{
* Correspondence: paul.fransen@ua.ac.ac

${ }^{1}$ Laboratory of Physiopharmacology, University of Antwerp, Universiteitsplein

1 Building T, 2.18, Wilrijk B-2610, Belgium

Full list of author information is available at the end of the article
} 


\section{Background}

Transcripts and protein expression of the $\mathrm{Ca}^{2+}$ channel gene are found widely in the cardiovascular system, where the channels play a dominant role in blood pressure regulation [1-5]. This regulation not only occurs via modulation of peripheral resistance, but also via determination of the arterial compliance, especially in old age (systolic) hypertension [6-8]. It has been shown that Ltype $\mathrm{Ca}^{2+}$ channel blockers increase vascular compliance of large elastic vessels. As such, they may also be of importance for the pathogenesis and prognosis of cardiovascular complications such as atherosclerosis, left ventricular hypertrophy and heart failure [8-14]. Vascular reactivity via L-type $\mathrm{Ca}^{2+}$ influx is often studied by increasing the extracellular $\mathrm{K}^{+}$and depolarizing the cell's membrane potential $\left(\mathrm{V}_{\mathrm{m}}\right)$. High $\mathrm{K}^{+}$induces biphasic contractions in rabbit arteries [15], rat basilar arterial rings [16] and mouse aorta [17], whereby the tonic rise in force is actually accompanied by a decline of intracellular $\mathrm{Ca}^{2+}$. This is often attributed to $\mathrm{Ca}^{2+}$-sensitization, whereby suppression of myosin light chain phosphatase activity raises contractile force independently of further increases or even decrease in intracellular $\mathrm{Ca}^{2+}[15,18-21]$. In those studies, however, relationships between force and continuous background $\mathrm{Ca}^{2}$ influx via non-inactivating L-type $\mathrm{Ca}^{2+}$ channels were not explored.

Indeed, (electro)physiological characteristics of L-type $\mathrm{Ca}^{2+}$ channels, which have been studied extensively in isolated cardiomyocytes and vascular smooth muscle cells (VSMCs), are such that voltage-dependent activation and inactivation curves show substantial overlap between -40 and $-15 \mathrm{mV}$ revealing a time-independent, but voltage-dependent $\mathrm{Ca}^{2+}$ influx (window current) in isolated cells [22-26]. Although pharmacological evidence suggested that this window may at least serve as a background $\mathrm{Ca}^{2+}$ influx pathway responsible for myogenic tone of small arteries, coronary arteries and microvascular resistance vessels [27-29], window $\mathrm{Ca}^{2+}$ currents and related window intracellular $\mathrm{Ca}^{2+}$ signals have only been determined in voltage-clamped isolated SMCs and not in multicellular vascular tissue [24]. The present study used aortic segments of C57Bl6 mice to investigate relationships between VSMC $\mathrm{Ca}^{2+}$ mobilization and isometric contraction with focus on the L-type $\mathrm{Ca}^{2+}$ channel window. Since electrophysiological voltage-clamp of intact aorta segments was impossible, we decided to clamp the membrane potential at fixed potentials by increasing external $\mathrm{K}^{+}$concentration. By modulating influx of $\mathrm{Ca}^{2+}$ before and during depolarization, we show that not only basal tension, but also the tonic contractile component of C57Bl6 mouse aortic VSMCs depends on the window L-type $\mathrm{Ca}^{2+}$ influx and subsequent $\mathrm{Ca}^{2+}$ sensitization mechanisms. These observations may have important consequences for the effects of nitric oxide (NO) on L-type $\mathrm{Ca}^{2+}$ influx. Recently, we showed that the relaxing efficacy of NO in mouse aorta was dependent on the contractile agonist, and more specifically, decreased when the contraction was mainly elicited via L-type $\mathrm{Ca}^{2+}$ influx as with elevated extracellular $\mathrm{K}^{+}$, but increased when $\mathrm{Ca}^{2+}$ influx was partially inhibited with L-type $\mathrm{Ca}^{2+}$ channel blockers [30].

\section{Results}

\section{Contraction at depolarized potentials}

Membrane potentials $\left(\mathrm{V}_{\mathrm{m}}\right)$ in intact mouse aortic VSMCs were $\mathrm{K}^{+}$-dependent and depolarised from $-60 \mathrm{mV}$ at $5.9 \mathrm{mM} \mathrm{K}^{+}$to $-30 \mathrm{mV}$ at $50 \mathrm{mM} \mathrm{K}^{+}$(see Additional file 1). Hence, elevation of extracellular $\mathrm{K}^{+}$is a good method to clamp multicellular aortic segments from resting potentials at $5.9 \mathrm{mM} \mathrm{K}^{+}$to depolarized potentials. Two $\mathrm{K}^{+}$clamp protocols, as shown in Figure 1, were used; they differed in the relative number of L-type $\mathrm{Ca}^{2+}$ channels that can be activated with the subsequent depolarization. In the repetitive protocol (Figure $1 \mathrm{~A}-\mathrm{C}$ ), which mimics the depolarizing voltage steps in voltage-clamp experiments of single VSMCs, segments at $5.9 \mathrm{mM} \mathrm{K}^{+}$were repetitively exposed to elevated $\mathrm{K}^{+}$followed by return to $5.9 \mathrm{mM} \mathrm{K}^{+}$. In this protocol, the number of channels that can be activated by the depolarization step is always the same at the start of the depolarization. In the cumulative protocol (Figure 1 D-F), which mimics the variable holding potentials in voltage-clamp experiments in single VSMCs, the segments were depolarized to the subsequent higher $\mathrm{K}^{+}$concentration without return to $5.9 \mathrm{mM} \mathrm{K}^{+}$. Therefore, with this protocol the relative number of $\mathrm{Ca}^{2+}$ channels that can be activated with the subsequent depolarization decreases with higher $\mathrm{K}^{+}$.

Isometric force by the repetitive protocol followed a bi-exponential time course, except at $10 \mathrm{mM} \mathrm{K}^{+}$ (Figure 1A). Amplitude (Figure 1B) and velocity of the fast component increased with the $\mathrm{K}^{+}$concentration (time constant $27.1 \pm 6.0 \mathrm{~s}$ at $20 \mathrm{mM} \mathrm{K}^{+}, 3.8 \pm 0.7 \mathrm{~s}$ at $\left.124 \mathrm{mM} \mathrm{K}^{+}, \mathrm{P}<0.001\right)$. The amplitude of the slow component showed a maximum around $50 \mathrm{mM} \mathrm{K}^{+}$, but then significantly decreased at 90 and $124 \mathrm{mM} \mathrm{K}^{+}$ (Figure 1C). Remarkably, its time constant was independent of external $\mathrm{K}^{+}\left(258 \pm 34 \mathrm{~s}\right.$ at $20 \mathrm{mM} \mathrm{K}^{+}$and $253 \pm 27 \mathrm{~s}$ at $\left.124 \mathrm{mM} \mathrm{K}^{+}\right)$. [ $\left.\mathrm{K}^{+}\right]$-force relationships (Figure 1C) revealed $E_{\max }$-values of $6.1 \pm 0.5,9.4 \pm 1.3$ and $14.4 \pm 1.6 \mathrm{mN}$ for fast, slow and steady-state force. $\mathrm{EC}_{50}$ values were respectively $23.5 \pm 1.2,22.2 \pm 0.3$ and $22.0 \pm 0.3 \mathrm{mM} \mathrm{K}^{+}$and were not significantly different.

In the cumulative protocol, two force signals were seen at 15 and $20 \mathrm{mM} \mathrm{K}^{+}$: on top of a tonic rise upon depolarization, transient force spikes were observed (Figure 1D and E). These spikes faded away as time 


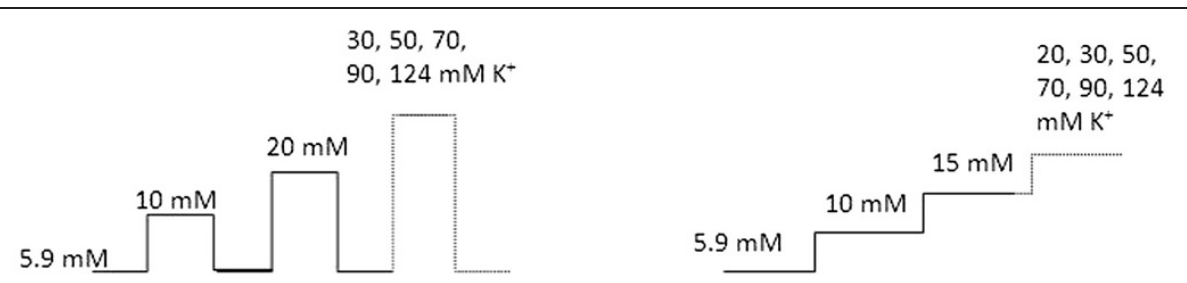

A

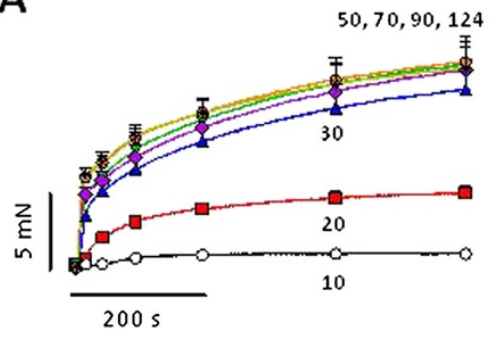

B
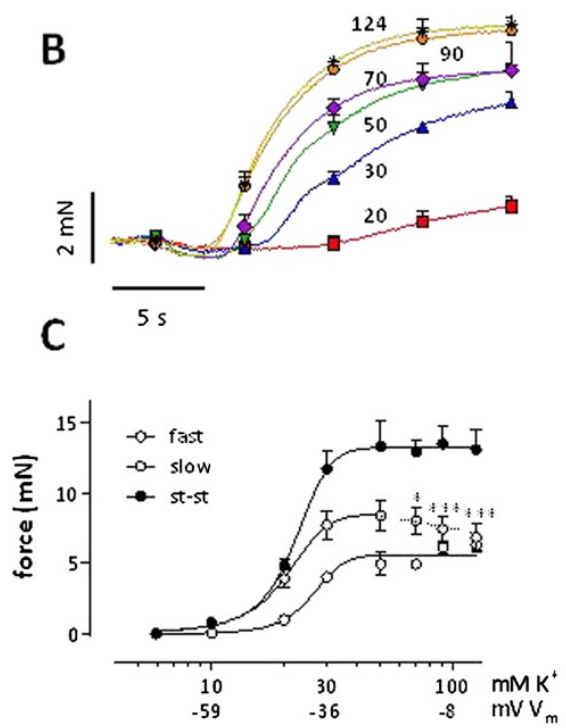

D

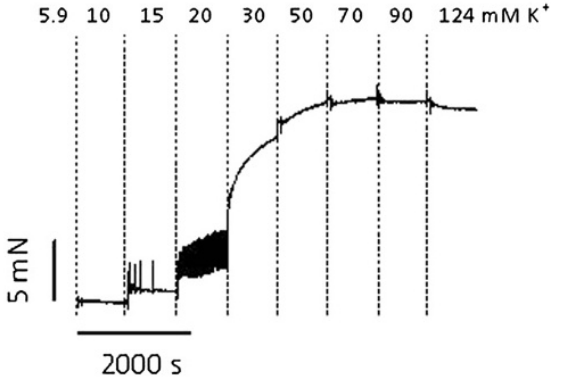

$E$

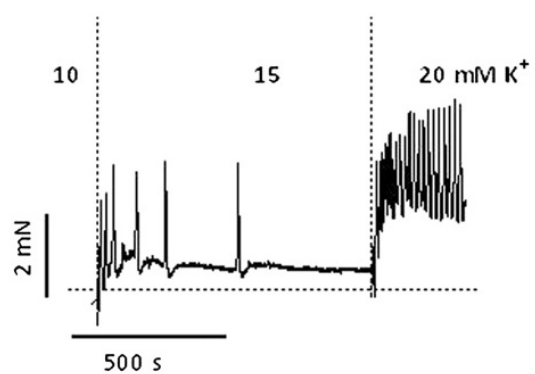

$\mathbf{F}$

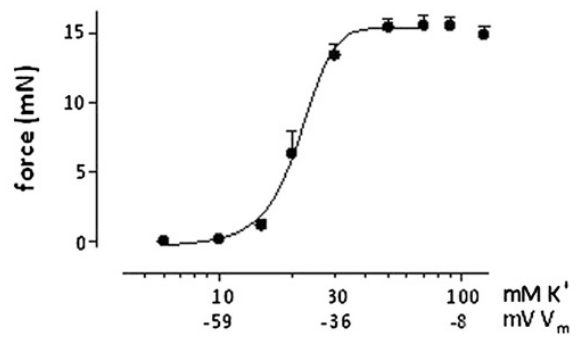

Figure 1 Isometric contractions by elevation of external $\mathbf{K}^{+}$in mouse aorta. $\mathrm{K}^{+}$was elevated from $5.9 \mathrm{mM}$ to $10,20,30,50,70,90$ or $124 \mathrm{mM} \mathrm{K}^{+}$according to the protocols shown in the top panels. For the repetitive protocol (A-C), traces, shown on condensed (A) and expanded (B) time scales, were analyzed with a bi-exponential function revealing $\left[\mathrm{K}^{+}\right]$-force curves for the fast, slow and steady-state (st-st) force components $(\mathbf{C})$. For the cumulative protocol (D-F), D shows a representative example of isometric force elicited by gradual elevations of extracellular $\mathrm{K}^{+}$. $\mathbf{E}$ displays the 5.9 to 10,10 to 15 and 15 to $20 \mathrm{mM} \mathrm{K}{ }^{+}$depolarizations on an expanded time scale. In $\mathbf{F}$ "steady-state" force at each step was plotted in function of $\left[K^{+}\right]$. Results show mean \pm s.e.m, $n=4(\mathbf{A}-\mathbf{C})$ or $n=5(\mathbf{F})$. ${ }^{*},{ }^{* * *}$ : $P<0.05,0.001$ decrease of slow component amplitude versus maximum at $50 \mathrm{mM} \mathrm{K}$. The estimated values of $\mathrm{V}_{\mathrm{m}}$ at 10,30 and $100 \mathrm{mM}\left[\mathrm{K}^{+}\right]$are indicated. These values are respectively -59 , -36 and $-8 \mathrm{mV}$ (see Additional file 1).

progressed $\left(15 \mathrm{mM} \mathrm{K}^{+}\right)$, and showed increased frequency, but similar amplitudes at $20 \mathrm{mM} \mathrm{K}^{+}$. At 30 and $50 \mathrm{mM} \mathrm{K}^{+}$ these spikes disappeared, but force developed with a fast and slow component. Above $50 \mathrm{mM} \mathrm{K^{+ }}$ only a small increase $\left(50-70 \mathrm{mM} \mathrm{K}^{+}\right)$or even a decrease $\left(90-124 \mathrm{mM} \mathrm{K}^{+}\right)$ of force was observed (Figure 1D). $\mathrm{E}_{\max }(15.5 \pm 0.6 \mathrm{mN}$, Figure $1 \mathrm{~F})$ and $\mathrm{EC}_{50}\left(21.8 \pm 1.2 \mathrm{mM} \mathrm{K}^{+}\right)$were not significantly different from the steady state values measured with repetitive depolarization (vide supra).
Neurotransmitter release from perivascular nerves did not contribute to the biexponential nature of high $\mathrm{K}^{+}$ contractions or to the $\mathrm{K}^{+}$-dose-response relationships in aortic segments (see Additional file 1). There was also no evidence of involvement of sarcoplasmic reticulum (SR) $\mathrm{Ca}^{2+}$ store $\mathrm{Ca}^{2+}$ release. Although inhibition of $\mathrm{Ca}^{2+}$-induced $\mathrm{Ca}^{2+}$ release with $15 \mu \mathrm{M}$ ryanodine raised basal tension (Figure 2A), and inhibited the transient caffeine-induced contraction by more than $50 \%$ 


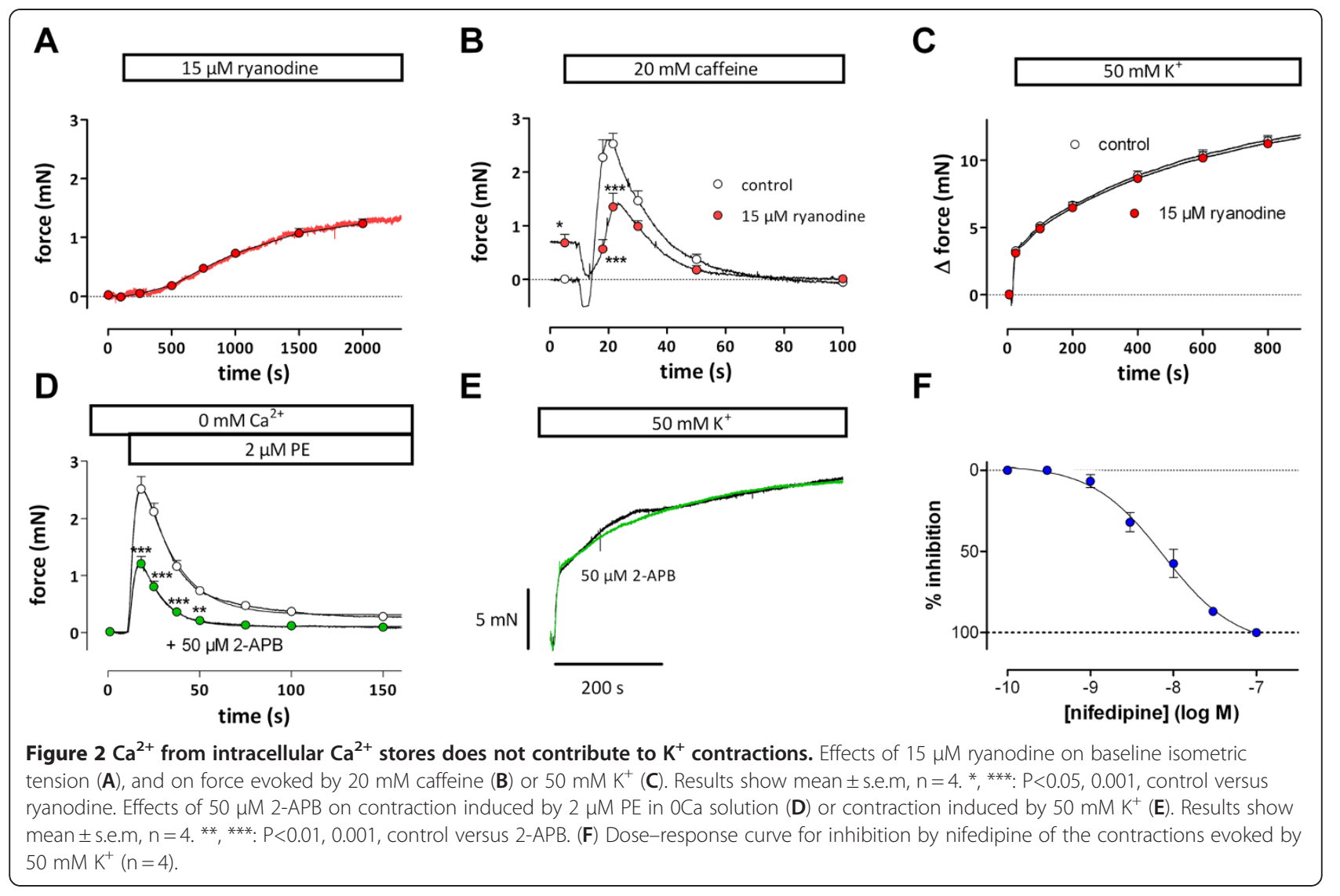

(Figure 2B), $50 \mathrm{mM} \mathrm{K} \mathrm{K}^{+}$-induced contractions were not affected (Figure 2C). Similar observations were made for inositoltriphosphate $\left(\mathrm{IP}_{3}\right)$-mediated $\mathrm{Ca}^{2+}$ release. Contractions by $2 \mu \mathrm{M}$ phenylephrine (PE) in the absence of extracellular $\mathrm{Ca}^{2+}$ were significantly reduced by $50 \mu \mathrm{M}$ 2-aminoethoxydiphenyl borate (2-APB), a blocker of $\mathrm{IP}_{3}$-induced $\mathrm{Ca}^{2+}$ release [31] (Figure 2D), whereas contractions by $50 \mathrm{mM} \mathrm{K}^{+}$were not affected (Figure $2 \mathrm{E}$ ).

Moreover, $\mathrm{K}^{+}$in $\mathrm{Ca}^{2+}$-free $\mathrm{KR}(0 \mathrm{Ca})$ or in the presence of $3 \mu \mathrm{M}$ nifedipine, an inhibitor of L-type $\mathrm{Ca}^{2+}$ channels, failed to elicit tension, and addition of nifedipine (3 to $300 \mathrm{nM}$ ) to segments constricted with $50 \mathrm{mM} \mathrm{K}^{+}$caused complete relaxation $\left(E_{\max } 107 \pm 3 \%, \log \mathrm{E}_{50}-8.12 \pm 0.12\right.$, $\mathrm{n}=4$, Figure 2F). Finally, inhibition of SERCA and emptying the intracellular $\mathrm{Ca}^{2+}$ stores with $1 \mu \mathrm{M}$ cyclopiazonic acid (CPA) did not affect the contraction by $50 \mathrm{mM} \mathrm{K}^{+}$.

These results indicated that $\mathrm{SR} \mathrm{Ca}^{2+}$ is not involved in $\mathrm{K}^{+}$-evoked contractions and that fast and slow force components evoked by high $\mathrm{K}^{+}$were both initiated and sustained by $\mathrm{Ca}^{2+}$ influx via VSMC L-type $\mathrm{Ca}^{2+}$ channels only.

\section{Relationship between force and $\mathrm{Ca}^{2+}$ influx}

Temporal relationships between intracellular $\mathrm{Ca}^{2+}$ and isometric force were explored using the cumulative protocol. For $\mathrm{K}^{+}$elevations from 15 to 20 , from 20 to 25 and from 25 to $30 \mathrm{mM} \mathrm{K}^{+}$, there was a strict temporal relationship between $\mathrm{Ca}^{2+}$ and force (Figure 3). Again, there were tonic and phasic contractions (cf Figure 1D and $\mathrm{E}$ ), though at slightly higher $\mathrm{K}^{+}$concentrations $\left(20-30 \mathrm{mM} \mathrm{K}^{+}\right)$. They coincided with phasic $\mathrm{Ca}^{2+}$ spikes on top of a tonic rise of $\mathrm{Ca}^{2+}$ (Figure 3). Both $\mathrm{Ca}^{2+}$ and force spikes faded away as time progressed (15 to $20 \mathrm{mM} \mathrm{K}^{+}$), displayed higher frequency at the subsequent step $\left(25 \mathrm{mM} \mathrm{K}^{+}\right)$and disappeared at holding potentials above $30 \mathrm{mM} \mathrm{K}^{+}$. From 35 up to $124 \mathrm{mM} \mathrm{K}^{+}$the temporal relationships between $\mathrm{Ca}^{2+}$ (transient peak tapering off to lower plateau) and force (biphasic increase) were not clear and during these depolarizations $\mathrm{Ca}^{2+}$ decreased whereas force increased (arrows in Figure 3).

The deviations between $\mathrm{Ca}^{2+}$ and force above $30 \mathrm{mM} \mathrm{K}^{+}$were studied in greater detail by depolarizing the segments from $5.9 \mathrm{mM} \mathrm{K} \mathrm{K}^{+}$to 50 or $124 \mathrm{mM} \mathrm{K}$. The initial, fast contraction was accompanied by a fast rise in $\mathrm{Ca}^{2+}$ (Figure 4). Amplitude and velocity of the fast $\mathrm{Ca}^{2+}(7.2 \pm 1.5 \mathrm{~s})$ and force $(7.7 \pm 1.2 \mathrm{~s})$ components were greater at $124 \mathrm{mM} \mathrm{K}^{+}$as compared with $50 \mathrm{mM} \mathrm{K}^{+}$ $(16.8 \pm 3.7 \mathrm{~s}$ and $14 \pm 3 \mathrm{~s}$ respectively). After reaching a maximum, $\mathrm{Ca}^{2+}$ declined faster $(50 \pm 6 \mathrm{~s}$ versus $137 \pm 24 \mathrm{~s}, \mathrm{P}<0.01)$ and to a lower level at $124 \mathrm{mM} \mathrm{K}^{+}$ 


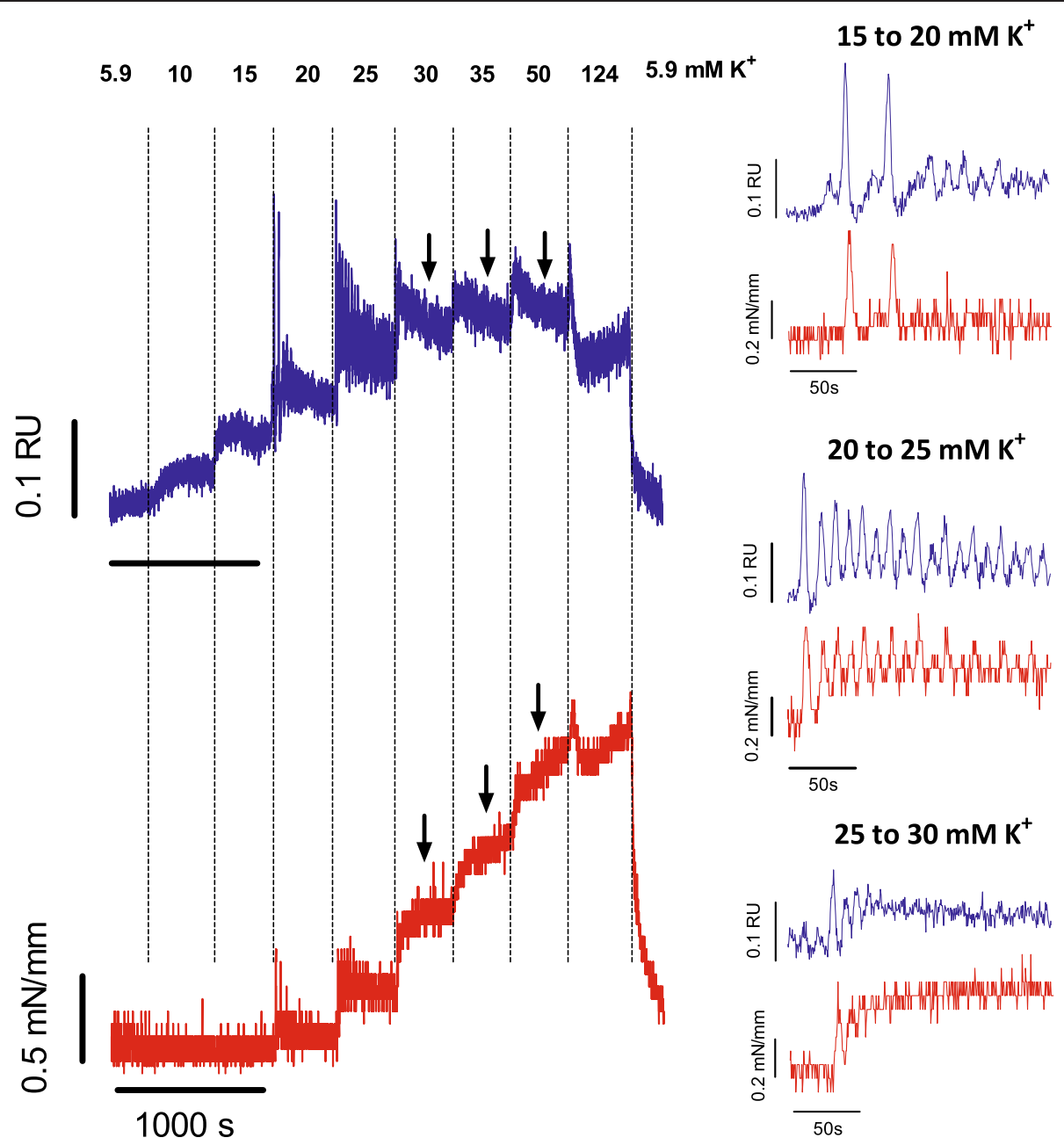

Figure 3 Depolarisation with elevated $\mathrm{K}^{+}$induces force and intracellular $\mathrm{Ca}^{2+}$ signals. Representative example $(\mathrm{n}=3)$ of intracellular $\mathrm{Ca}^{2+}$ (ratio 340/380, RU, blue) and isometric force (red) of an aortic segment upon gradual elevation of external $\mathrm{K}^{+}$from $5.9 \mathrm{mM}$ to the values indicated on top of the figure. Both signals are shown in the right panel on an extended time scale for transitions from 15 to 20 , from 20 to 25 and from 25 to 30. Black arrows indicate decrease of $\mathrm{Ca}_{i}^{2+}$ with accompanying increase of force.

than at $50 \mathrm{mM} \mathrm{K} \mathrm{K}^{+}$, and the slow force increase during the plateau phase was slightly smaller at $124 \mathrm{mM} \mathrm{K}^{+}$.

These results indicate that at 50 or $124 \mathrm{mM} \mathrm{K}^{+}$the slow contraction was actually accompanied by a decline of $\mathrm{Ca}^{2+}$, but that there was a good temporal relationship between intracellular $\mathrm{Ca}^{2+}$ and force development immediately after the depolarization.

\section{Experimental dissection of the $\mathrm{Ca}^{2+}$ and force components}

At $5.9 \mathrm{mM} \mathrm{K}^{+}$, removal of extracellular $\mathrm{Ca}^{2+}(0 \mathrm{Ca})$ decreased basal intracellular $\mathrm{Ca}^{2+}$ and force from $0.91 \pm 0.03$ to $0.81 \pm 0.02 \mathrm{RU}(\mathrm{p}<0.005, \mathrm{n}=6)$ and from $0.52 \pm 0.02$ to $0.40 \pm 0.05 \mathrm{mN} / \mathrm{mm}(\mathrm{p}<0.05, \mathrm{n}=6)$, indicating baseline $\mathrm{Ca}^{2+}$ influx via $\mathrm{Ca}^{2+}$ channels in normal conditions. Depolarizing the segments with $124 \mathrm{mM} \mathrm{K}^{+}$in $0 \mathrm{Ca}$ abrogated $\mathrm{Ca}^{2+}$ influx via L-type $\mathrm{Ca}^{2+}$ channels and neither contraction nor $\mathrm{Ca}^{2+}$ influx was observed. Because in the absence of extracellular $\mathrm{Ca}^{2+} \mathrm{L}$-type $\mathrm{Ca}^{2+}$ channels display normal gating currents [32], subsequent addition of external $\mathrm{Ca}^{2+}$ can evoke $\mathrm{Ca}^{2+}$ influx and contraction only if a subpopulation of L-type $\mathrm{Ca}^{2+}$ channels is not completely inactivated during the preceding depolarization in $0 \mathrm{Ca}$. Indeed, re-addition of $\mathrm{Ca}^{2+}$ to $0 \mathrm{Ca}$ caused intracellular $\mathrm{Ca}^{2+}$ and force to increase (Figure 5B). Contrary to the control situation (Figure 5A), intracellular $\mathrm{Ca}^{2+}$ did not decline during the contraction plateau in the $\mathrm{Ca}^{2+}$ re-addition experiments. As a consequence, a clear temporal relationship between the slow $\mathrm{Ca}^{2+}$ and force signals was observed (Figure 5B) and the force and $\mathrm{Ca}^{2+}$ signals could now be dissected in parallel fast and slow components.

The fast $\mathrm{Ca}^{2+}$ and force components that were eliminated in the $\mathrm{Ca}^{2+}$ re-addition experiments, could be 

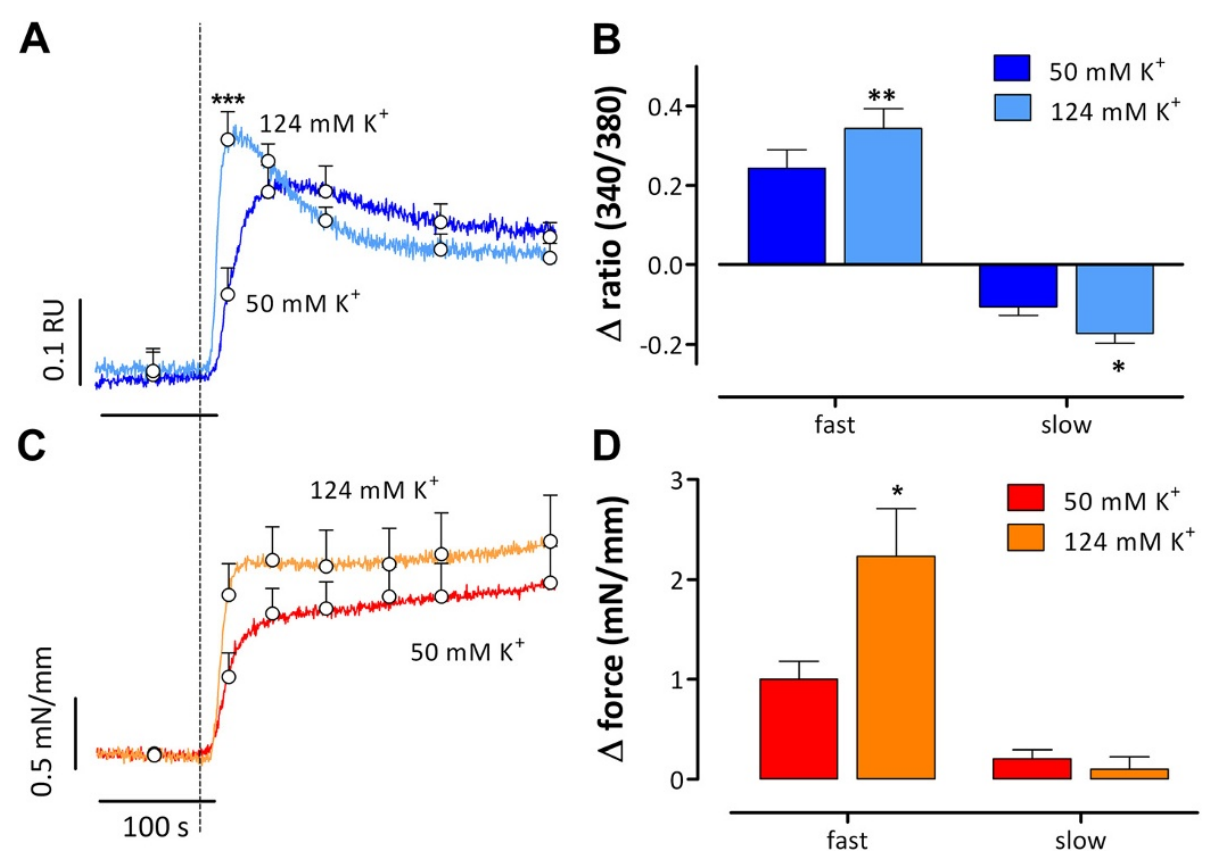

Figure 4 Temporal relationships between force and intracellular $\mathrm{Ca}^{2+}$ signals at elevated $\mathbf{K}^{+}$. Intracellular $\mathrm{Ca}^{2+}$ (ratio 340/380, RU, blue, A) and force (red, C) signals upon depolarization from $5.9 \mathrm{mM} \mathrm{K}^{+}$to 50 or $124 \mathrm{mM} \mathrm{K}^{+}$. Ca ${ }^{2+}$ and force signals consisted of fast and slow components with amplitudes shown in $\mathbf{B}$ and $\mathbf{D}$. Results show mean \pm s.e. $m, n=6 .{ }^{*},{ }^{* *}$, ***: $P<0.05,0.01,0.001$ for 124 versus $50 \mathrm{mM} \mathrm{K+}$.

visualized by pair-wise subtracting $\mathrm{Ca}^{2+}$ and force traces from control traces (Figure 5C, D). The differential $\mathrm{Ca}^{2+}$ and force signals displayed a similar time-dependency (time constants respectively $15 \pm 2 \mathrm{~s}$ and $9 \pm 2 \mathrm{~s}$ for rise, and $57 \pm 4 \mathrm{~s}$ and $54 \pm 4 \mathrm{~s}$ for fall). Therefore, Figures 4 and 5 illustrate the strict temporal relationships between fast and slow $\mathrm{Ca}^{2+}$ and force signals upon depolarization: the fast transient $\mathrm{Ca}^{2+}$ increase during depolarization
A
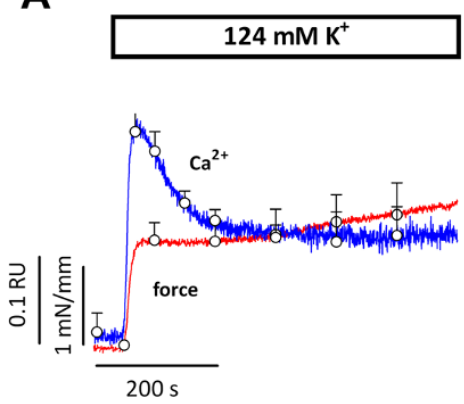

C

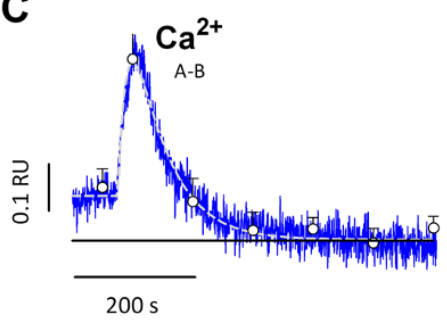

B

$124 \mathrm{mM} \mathrm{K}^{+}, 0 \mathrm{mM} \mathrm{Ca}^{2+}$

$3.5 \mathrm{mM} \mathrm{Ca}^{2+}$

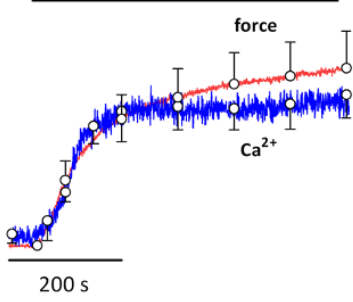

D

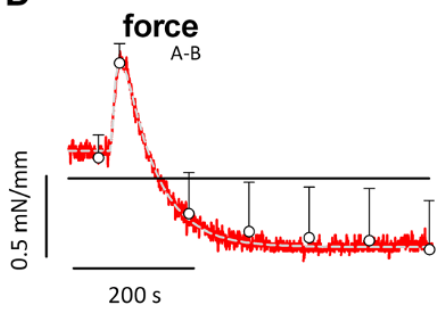

Figure 5 Depolarization in the absence of external $\mathrm{Ca}^{2+}$ eliminates the fast, transient $\mathrm{Ca}_{\mathbf{i}}{ }^{2+}$ and force signals. Intracellular $\mathrm{Ca}^{2+}$ (ratio $340 / 380$, blue) and force (red) upon depolarization from $5.9 \mathrm{mM} \mathrm{K}^{+}$to $124 \mathrm{mM} \mathrm{K}^{+}$in the presence of $2.5 \mathrm{mM}$ external Ca ${ }^{2+}\left(124 \mathrm{mM} \mathrm{K}^{+}, \mathbf{A}\right)$ or after re-addition of $3.5 \mathrm{mM} \mathrm{Ca}^{2+}$ to 0Ca (124 Kº-3.5Ca, B). Pair-wise subtraction of $124 \mathrm{mM} \mathrm{K}^{+} / 0-3.5 \mathrm{Ca}$ from $124 \mathrm{mM} \mathrm{K}^{+}$signals yielded the differential curves for $\mathrm{Ca}^{2+}(\mathbf{C})$ and force (D). Results show mean \pm s.e. $\mathrm{m}, \mathrm{n}=4$. 
initiates fast force development, whereas a simultaneously activated slower influx of $\mathrm{Ca}^{2+}$ is responsible for sustained force development during the plateau phase.

\section{Is $\mathrm{L}$-;type $\mathrm{Ca}^{2+}$ window current responsible for the slow contraction phase?}

An important electrophysiological property of L-type $\mathrm{Ca}^{2+}$ channels is that in the voltage range where activation and inactivation curves overlap, they allow a continuous, time-independent $\mathrm{Ca}^{2+}$ influx, the so-called window L-type $\mathrm{Ca}^{2+}$ channel current $[24,26]$. If this current is responsible for the slow contraction phase following addition of external $\mathrm{Ca}^{2+}$ to segments depolarized in $0 \mathrm{Ca}$, then force should display a bell-shaped concentration-response relationship. Figure 6 shows the contractions evoked by re-introduction of $\mathrm{Ca}^{2+}$ to $0 \mathrm{Ca}$ at different $\mathrm{K}^{+}$concentrations. After $200 \mathrm{~s}$ the slow component showed a linear rather than exponential increase with time. Force measured at $600 \mathrm{~s}$ was maximal at $50 \mathrm{mM} \mathrm{K}^{+}$and declined at higher $\mathrm{K}^{+}$concentrations (Figure 6A).

$\left[\mathrm{K}^{+}\right]$-contraction curves were determined after 200, 400 and $600 \mathrm{~s}$ (Figure 6B and C). At these time intervals, the $\left[\mathrm{K}^{+}\right]$-contraction curve indeed became bell-shaped. The bell-shape and the complete inhibition with the Ltype $\mathrm{Ca}^{2+}$ channel blocker, nifedipine (data not shown) are typical characteristics of the window L-type $\mathrm{Ca}^{2+}$ current. The $\mathrm{EC}_{50}$ for $\mathrm{K}^{+}$was time-independent and was respectively $20.9 \pm 0.4 \mathrm{mM}, \quad 20.4 \pm 0.2 \mathrm{mM}$ and $20.5 \pm 0.2 \mathrm{mM}(\mathrm{n}=6)$. The continuous increase of force with time is presumably due to $\mathrm{Ca}^{2+}$ sensitization as intracellular $\mathrm{Ca}^{2+}$ reached steady-state after $200 \mathrm{~s}$ (Figure 5). Further evidence for $\mathrm{Ca}^{2+}$ sensitization was provided by Rho kinase inhibition with Y-27632 (1 and $3 \mu \mathrm{M})$. Y27632 attenuated depolarization-induced contractions, but inhibition of $\mathrm{Ca}^{2+}$ sensitization emphasized the bell shape of the $\left[\mathrm{K}^{+}\right]$-contraction curve even more. This suggests that the decrease of force at 90 and $124 \mathrm{mM} \mathrm{K}^{+}$ was not due to a reduction in sensitivity to $\mathrm{Ca}^{2+}$, but was proportional to the window influx of $\mathrm{Ca}^{2+}$ via $\mathrm{L}$ type $\mathrm{Ca}^{2+}$ channels (Figure 7). Similar results were obtained with HA 1077 (5 $\mu \mathrm{M}$, not shown).

\section{Modulation of L-type window $\mathrm{Ca}^{2+}$ influx}

Changes of $V_{m}$ of the VSMCs or changes of the voltagedependent parameters of L-type $\mathrm{Ca}^{2+}$ channel gating (activation or inactivation) are expected to affect $\mathrm{Ca}^{2+}$ influx and contraction of the segments. Segments could be hyperpolarized from $-60 \mathrm{mV}$ to the $\mathrm{K}^{+}$equilibrium potential $\left(\mathrm{V}_{\mathrm{K}}\right)$ of $-86 \mathrm{mV}$ at $5.9 \mathrm{mM} \mathrm{K}^{+}$with levcromaka$\lim (200 \mathrm{nM})$, an opener of ATP-dependent $\mathrm{K}^{+}$channels (see Additional file 1, Figure 1). The L-type $\mathrm{Ca}^{2+}$ channel activation curve can be shifted to hyperpolarized potentials with BAY K8644 (30 nM), an activator of L-type
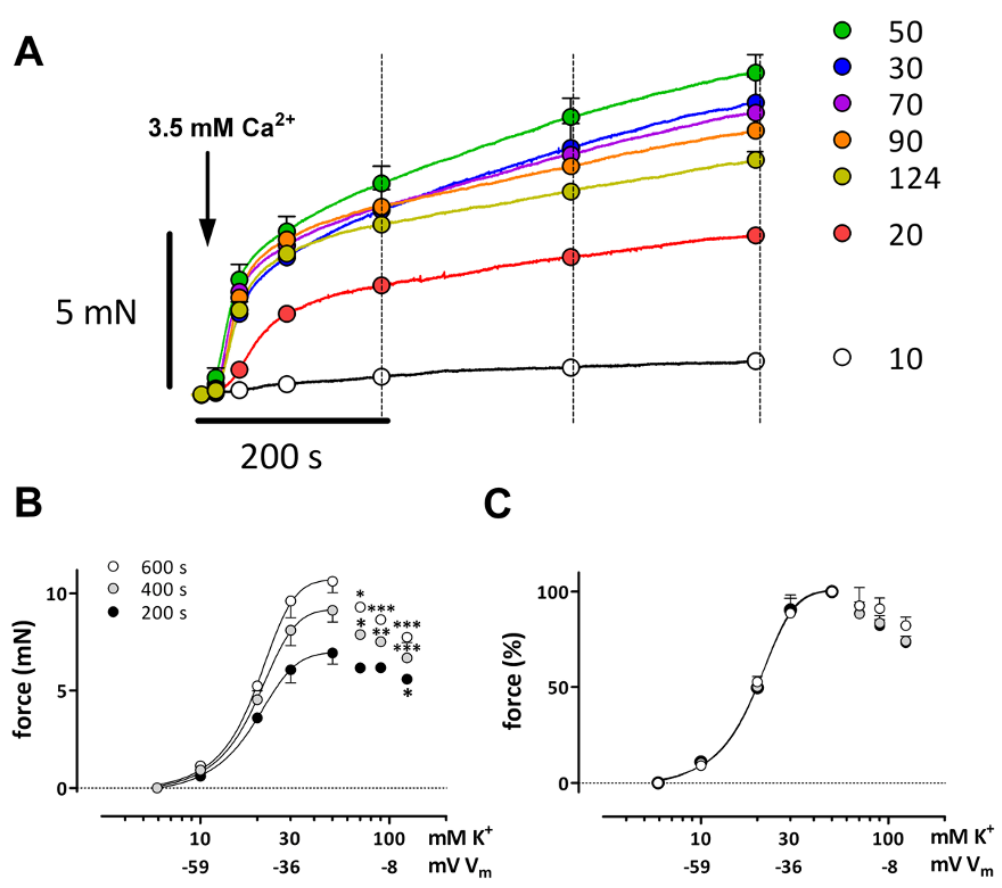

Figure $6 \mathrm{~K}^{+}$-dependent development of window contraction. Isometric contractions induced by addition of $3.5 \mathrm{mM} \mathrm{Ca}{ }^{2+}$ to $0 \mathrm{Ca}$ containing 10 up to $124 \mathrm{mM} \mathrm{K}^{+}(\mathbf{A})$. Absolute $(\mathbf{B})$ and relative $\left(50 \mathrm{mM} \mathrm{K}^{+}\right.$set to $\left.100 \%, \mathbf{C}\right)\left[\mathrm{K}^{+}\right]$-force curves were determined at 200,400 and $600 \mathrm{~s}$ (see dotted lines in $\mathbf{A}$ ), were bell-shaped and could only be fitted up to $50 \mathrm{mM} \mathrm{K}^{+}(\mathbf{B}, \mathbf{C})$. Results show mean \pm s.e.m, $n=6 .{ }^{*}, * * * * *$ : $P<0.05,0.01$, 0.001 versus $50 \mathrm{mM} \mathrm{K}$ 
A

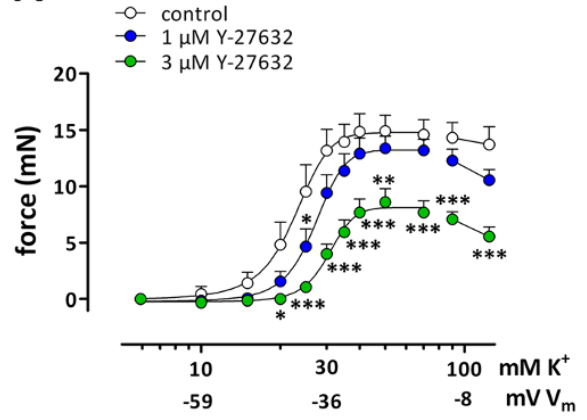

B

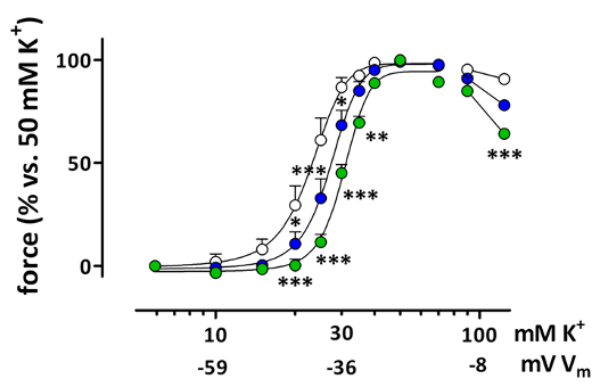

Figure 7 Effects of Rho kinase inhibition with Y-27632 on window contractions. A: "Steady-state" isometric contractions induced by depolarizations with cumulative $\mathrm{K}^{+}$concentrations in the absence (control) and in the presence of 1 and $3 \mu \mathrm{M}$ Y-27632. In $\mathbf{B}$, force was normalized with values at $50 \mathrm{mM} \mathrm{K}{ }^{+}$as $100 \%$. Results show mean \pm s.e.m, $n=4 .{ }^{*},{ }^{* *}$, ***: $\mathrm{P}<0.05,0.01,0.001$ versus control.

$\mathrm{Ca}^{2+}$ channels $[30,33,34]$. When segments were subjected to increasing $\mathrm{K}^{+}$concentrations in the presence of levcromakalim, BAY K8644, or their combination (Figure $8 \mathrm{~A}$ and $\mathrm{B}$ ), levcromakalim shifted the curve to higher $\mathrm{K}^{+}$concentrations $(+5.93 \pm 0.87 \mathrm{mM})$, whereas BAY K8644 caused a shift to lower $\mathrm{K}^{+}$concentrations $(-7.98 \pm 1.09 \mathrm{mM})$. Both effects were fully additive, indicating independent effects of $\mathrm{V}_{\mathrm{m}}$ (levcromakalim) and L-type $\mathrm{Ca}^{2+}$ channel gating (BAY K8644) on window contractions.

At normal extracellular $\mathrm{K}^{+}$, levcromakalim caused a glibenclamide (inhibitor of ATP-sensitive $\mathrm{K}^{+}$channels)sensitive decline of intracellular $\mathrm{Ca}^{2+}(-0.042 \pm 0.012 \mathrm{RU}$, $\mathrm{n}=3)$ and baseline tension $(-0.56 \pm 0.28 \mathrm{mN}, \mathrm{n}=4)$, whereas BAY K8644 raised resting intracellular $\mathrm{Ca}^{2+}$ $(+0.016 \pm 0.008 \mathrm{RU})$ and force $(+1.77 \pm 0.51 \mathrm{mN}, \mathrm{n}=4)$. The BAY effect could be reversed by addition of levcromakalim or nifedipine (data not shown). To illustrate the physiological importance of the window $\mathrm{Ca}^{2+}$ influx for basal contraction of mouse aortic segments, the external $\mathrm{K}^{+}$concentration was changed to obtain depolarizations or repolarizations within the physiological range of $\mathrm{V}_{\mathrm{m}}$ for VSMCs (Figure 8C). Changes of the extracellular $\mathrm{K}^{+}$between 2 and $15 \mathrm{mM}$ and $\mathrm{V}_{\mathrm{m}}$ between -77 and $-51 \mathrm{mV}$ caused significant alterations of basal force in control, which could be amplified by adding $30 \mathrm{nM}$ BAY K8644 or removed by adding 200 nM levcromakalim (data not shown). These data provide further evidence for the importance of window $\mathrm{Ca}^{2+}$ influx within the physiological range of $\mathrm{V}_{\mathrm{m}}$ or $\mathrm{K}^{+}$concentrations $[35,36]$.

\section{Discussion and conclusions}

The present study showed that the main determinant of depolarization-induced contractions of the mouse aorta was the influx of extracellular $\mathrm{Ca}^{2+}$ via $\mathrm{L}$-type $\mathrm{Ca}^{2+}$ channels. Thereby, both $\mathrm{Ca}^{2+}$ influx and contraction depended on the amplitude of depolarization (reflected by the increase of external $\mathrm{K}^{+}$) and on the resting potential of the VSMC (concentration of external $\mathrm{K}^{+}$at the start of depolarization). At resting membrane potentials, elevation of extracellular $\mathrm{K}^{+}$above $10-20 \mathrm{mM}$ caused biphasic contractions and $\mathrm{Ca}^{2+}$ signals. Although the relationships between intracellular $\mathrm{Ca}^{2+}$ and force appeared to be complex and sometimes non-linear (slow component), we demonstrated that the fast, phasic force component was related to a transient $\mathrm{Ca}^{2+}$ influx, presumably via a population of L-type $\mathrm{Ca}^{2+}$ channels which activated and completely inactivated during the depolarization. On the other hand, the slow, tonic force component displayed a bell-shaped voltage $\left(\mathrm{K}^{+}\right)$-dependence and could be attributed to voltage-dependent, "steady state" $\mathrm{Ca}^{2+}$ influx via a population of L-type $\mathrm{Ca}^{2+}$ channels. These channels did not completely inactivate during sustained depolarization and gave rise to a window contraction. In addition to the $\mathrm{Ca}^{2+}$ influx via both populations of L-type $\mathrm{Ca}^{2+}$ channels, a time-dependent $\mathrm{Ca}^{2+}$ sensitization contributed to the depolarizationinduced contractions of the mouse aorta.

Depolarization-induced contraction is due to activation of L-type $\mathrm{Ca}^{2+}$ channels and not to $\mathrm{Ca}^{2+}$ release from the SR As expected [37], contractions induced by high $\mathrm{K}^{+}$were mainly due to influx of extracellular $\mathrm{Ca}^{2+}$ via L-type $\mathrm{Ca}^{2+}$ channels in the mouse aorta. Firstly, depolarization in the absence of external $\mathrm{Ca}^{2+}$ did not elicit intracellular $\mathrm{Ca}^{2+}$ signals or contractions. Secondly, selective L-type $\mathrm{Ca}^{2+}$ channel blockade ( $3 \mu \mathrm{M}$ nifedipine) completely inhibited $\mathrm{K}^{+}$-induced contractions. Thirdly, BAY K8644, an agonist of L-type $\mathrm{Ca}^{2+}$ channels, increased the $\mathrm{K}^{+}$-sensitivity of the contractions. Finally, although intracellular $\mathrm{Ca}^{2+}$ release or $\mathrm{Ca}^{2+}$-induced $\mathrm{Ca}^{2+}$ release through activation of $\mathrm{IP}_{3}$ or ryanodine receptors or $\mathrm{Ca}^{2+}$ re-uptake to the SR have been shown to contribute to $\mathrm{K}^{+}$-induced contractions $[16,37,38]$, this was not observed in mouse aorta segments (see also [24]). Hence, intracellular $\mathrm{Ca}^{2+}$ release 


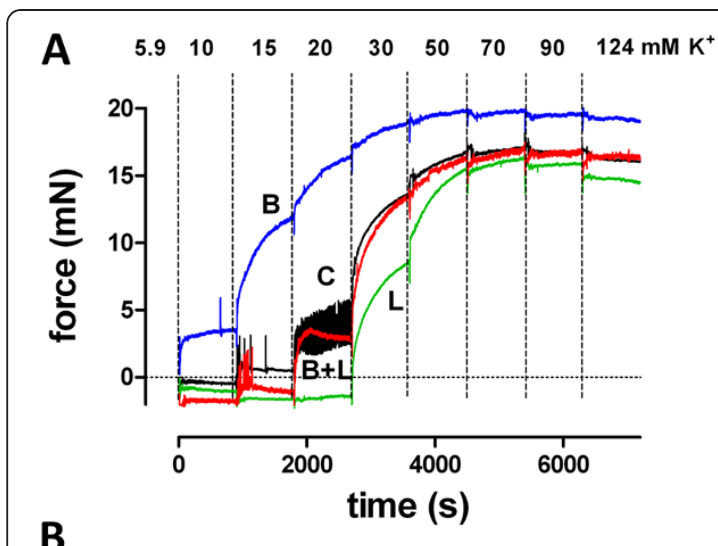

B

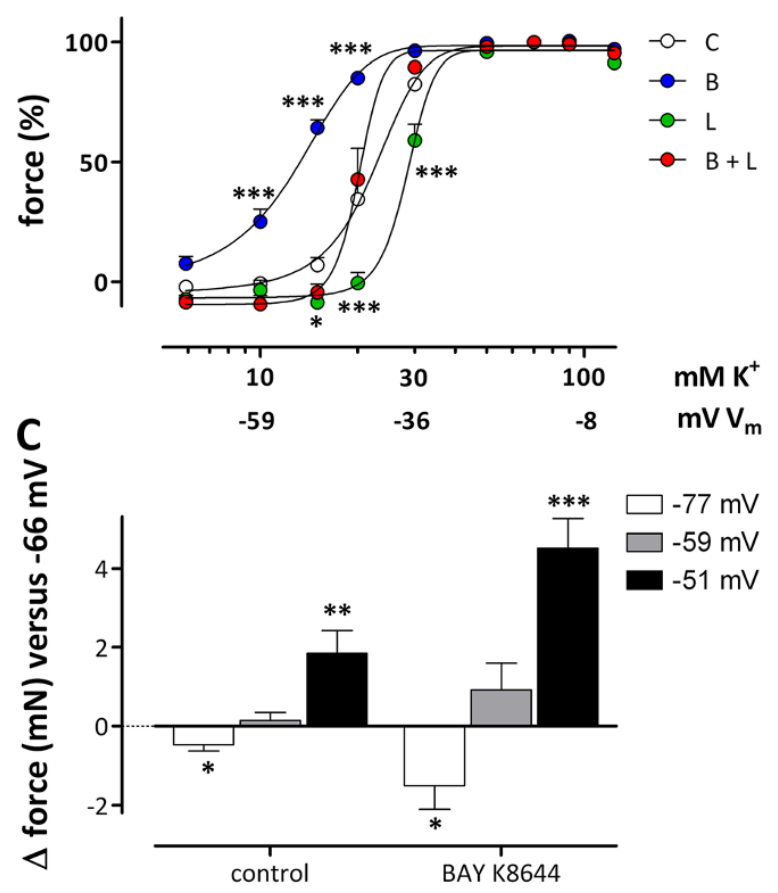

Figure 8 Stimulation and inhibition of window contraction. A: Representative example of isometric contractions of a segment depolarized with cumulative $\mathrm{K}^{+}$concentrations in the absence ( $C$, black) and presence of $30 \mathrm{nM}$ BAY K8644 (B, blue), $200 \mathrm{nM}$ levcromakalim ( $L$, green), or their combination $(B+L$, red). $\mathbf{B}$ : "Steady-state" force at each step was plotted as function of $\left[\mathrm{K}^{+}\right]$with values at $50 \mathrm{mM} \mathrm{K}^{+}$as $100 \%$. Results show mean \pm s.e.m, $\mathrm{n}=4$. * ${ }^{*}$,**: $\mathrm{P}<0.05,0.001$ versus control. $\mathrm{C}$ : Change of basal tension ( $\Delta$ force in $\mathrm{mN}$ ) for repolarization and depolarization of $V_{m}$ by changing extracellular $\mathrm{K}^{+}$to attain $\mathrm{V}_{\mathrm{m}}$ within the physiological range for non-stimulated VSMCs ( $K^{+}$from 5.9 mM to 2 (white) or 10 (grey) or 15 (black) $\mathrm{mM}$ ) in control conditions (C) and in the presence of $30 \mathrm{nM}$ BAY K8644 (B). Instead of the actual $\mathrm{K}^{+}$concentration, the estimated $V_{m}$ of the VSMCs is indicated: $-77 \mathrm{mV}$ for $2 \mathrm{mM},-66 \mathrm{mV}$ for $5.9 \mathrm{mM}$, (not shown), $-59 \mathrm{mV}$ for $10 \mathrm{mM}$ and $-51 \mathrm{mV}$ for $15 \mathrm{mM} \mathrm{K}^{+}$. Results show mean \pm s.e.m, $n=5 .{ }^{*},{ }^{* *},{ }^{* * *}: \mathrm{P}<0.05,0.01,0.001$ versus $5.9 \mathrm{mM} \mathrm{K}^{+}$.

did not account for the biphasic pattern of high $\mathrm{K}^{+}$-induced force and $\mathrm{Ca}_{\mathrm{i}}^{2+}$ and either phase was solely initiated by L-type $\mathrm{Ca}^{2+}$ influx.
Relationships between fast and slow contraction phases and $\mathrm{Ca}^{2+}$ influx

The contraction elicited by depolarization of VSMCs has been studied extensively [39], but has never been directly correlated with the known electrophysiological properties of L-type $\mathrm{Ca}^{2+}$ channels. L-type $\mathrm{Ca}^{2+}$ currents in isolated SMCs of various tissues and species display a bell-shaped voltage-dependence with maximal currents at 0 to $+20 \mathrm{mV}[1,2,14,22,23,25,40]$. Activation (opening) of L-type $\mathrm{Ca}^{2+}$ channels starts at -50 to $-40 \mathrm{mV}$ with half-maximal activation at $-30 \mathrm{mV}[25,41]$, whereas inactivation starts at $-60 \mathrm{mV}$, is half maximal at about $-30 \mathrm{mV}$ and complete at $0 \mathrm{mV}[23,25,41,42]$. As a consequence, at voltages between current activation (around $-45 \mathrm{mV}, 20$ to $25 \mathrm{mM} \mathrm{K}^{+}$) and complete current inactivation (around $0 \mathrm{mV}, 124 \mathrm{mM} \mathrm{K}^{+}$), two populations of L-type $\mathrm{Ca}^{2+}$ channels are expected to contribute to $\mathrm{Ca}^{2+}$ influx and contraction. One population of channels will activate and completely inactivate during the depolarization leading to a transient $\mathrm{Ca}^{2+}$ influx and concomitant contraction (see Figure 5C and D). This contraction corresponds with the fast phase of contraction as described in Figure $1 \mathrm{C}$, where it was elicited by step depolarizations of $\mathrm{V}_{\mathrm{m}}$ by sudden increase of $\mathrm{K}^{+}$ from $5.9 \mathrm{mM}$ to values above $20 \mathrm{mM}$. The physiological importance of these events in VSMCs can be questioned. However, in some experiments (Figure 3), fast time- and voltage-dependent intracellular $\mathrm{Ca}^{2+}$ and force spikes appeared on top of a slow rise in tone or $\mathrm{Ca}^{2+}$ at 15 to $20 \mathrm{mM} \mathrm{K}^{+}(-50$ to $-44 \mathrm{mV})$, which is near the activation voltage of L-type $\mathrm{Ca}^{2+}$ channels and within the physiological range of VSMCs $\mathrm{V}_{\mathrm{m}}$. As their spiking frequency increased with the amplitude of the depolarization step, fusing to a single fast component at 30 and $50 \mathrm{mM} \mathrm{K}^{+}(-36$ and $-24 \mathrm{mV})$ similar to the fast component in the step protocol, these events might be related with activation and complete inactivation of $\mathrm{L}$ type $\mathrm{Ca}^{2+}$ channels. Because they occur at physiological $\mathrm{V}_{\mathrm{m}}$ of VSMCs, they may have physiological importance. They may be related with the persistent calcium sparklets that are increased in hypertension [43], with artery vasospasm [44] or other pathophysiological processes.

However, at all $\mathrm{K}^{+}$concentrations studied, a variable population of channels will not completely inactivate and will permit "time-independent" $\mathrm{Ca}^{2+}$ influx via the so-called voltage window [24]. Hence, every depolarization positive to $-45 \mathrm{mV}\left( \pm 20 \mathrm{mM} \mathrm{K}^{+}\right)$should activate a time-independent, non-inactivating $\mathrm{Ca}^{2+}$ influx. Following removal of the fast force component by depolarization in the absence of external $\mathrm{Ca}^{2+}$ and, then, re-adding $\mathrm{Ca}^{2+}$ (Figures 5 and 6) we demonstrated that this "window" contraction showed a close temporal relationship with the increase of intracellular $\mathrm{Ca}^{2+}$ via window L-type $\mathrm{Ca}^{2+}$ influx. The electrophysiological 
characteristics of the L-type $\mathrm{Ca}^{2+}$ channel window, i.e. maximal $\mathrm{Ca}^{2+}$ influx at $-30 \mathrm{mV}\left(40\right.$ to $\left.50 \mathrm{mM} \mathrm{K}^{+}\right)$and a bell-shaped voltage-dependence are paralleled by a tonic force component which increased with $\left[\mathrm{K}^{+}\right]$up to 50 or $70 \mathrm{mM}\left(\mathrm{V}_{\mathrm{m}}=-20\right.$ to $\left.-30 \mathrm{mV}\right)$, but decreased again above $70 \mathrm{mM} \mathrm{K}$, leading to a bell-shaped $\left[\mathrm{K}^{+}\right]$-contraction curve. Its voltage range is bounded at negative potentials by channel activation and at more positive potentials by channel inactivation. This agrees with the $\mathrm{K}^{+}$-dependence of the slow force component described in Figure $1 \mathrm{C}$ and Figure 6.

\section{Manipulation of the window $\mathrm{Ca}^{2+}$ influx and contraction}

Our experiments predict that basal force by aortic segments will depend on $\mathrm{V}_{\mathrm{m}}$ and that changes of $\mathrm{V}_{\mathrm{m}}$ within the voltage range of the L-type $\mathrm{Ca}^{2+}$ channel window will stimulate or inhibit $\mathrm{Ca}^{2+}$ influx via L-type $\mathrm{Ca}^{2+}$ channels and the concomitant contraction. Since removal of extracellular $\mathrm{Ca}^{2+}$ led to a decline of intracellular $\mathrm{Ca}^{2+}$ and basal tension in the VSMC of the mouse aorta, a "window" $\mathrm{Ca}^{2+}$ influx appeared to be operative and functional at resting potentials, which are between -40 to $-60 \mathrm{mV}$ $[45,46]$. As a consequence, a small decrease $(2 \mathrm{mM} \mathrm{K}$, repolarization) or increase $\left(10 \mathrm{mM} \mathrm{K}^{+}\right.$, depolarization) of external $\mathrm{K}^{+}$modulates basal tension of the mouse aortic segments, probably via closing and opening of L-type $\mathrm{Ca}^{2+}$ channels because the effects of $\mathrm{K}^{+}$changes are emphasized by applying BAY K8644 (Figure 8C).

Hyperpolarization of $\mathrm{V}_{\mathrm{m}}$, as with EDHF [35,36,47-49] or with $K_{\text {ATP }}$ channel openers such as levcromakalim (present study) or cromakalim [45], or with reduction of extracellular $\mathrm{K}^{+}$might pull $\mathrm{V}_{\mathrm{m}}$ out of the window, thereby decreasing L-type $\mathrm{Ca}^{2+}$ influx, inducing vasodilatation, elevated arterial compliance [50], and hypotension. For example, in the present study, levcromakalim, which causes hyperpolarization to $V_{K}$ of $-85 \mathrm{mV}$ at $5.9 \mathrm{mM} \mathrm{K}^{+}$[47], caused a decline of resting intracellular $\mathrm{Ca}^{2+}$ and baseline tension, and shifted the $\left[\mathrm{K}^{+}\right]$-contraction curve to higher $\mathrm{K}^{+}$concentrations by $+6 \mathrm{mM} \mathrm{K}^{+}$at midpoint.

On the other hand, it is expected that factors causing depolarization of the membrane potential such as intravascular pressure [51], hypertension [2,52], a deficient $\mathrm{NO}$ release as in $\mathrm{eNOS}^{-/-}$mice [45], the absence of TRPC6 channels [46] might force the VSMC $\mathrm{V}_{\mathrm{m}}$ in the L-type $\mathrm{Ca}^{2+}$ channel window leading to increased window L-type $\mathrm{Ca}^{2+}$ influx, basal constriction, decreased arterial compliance, increased myogenic responses and hypertension.

Therefore, results of the present study indicate that the position of the L-type $\mathrm{Ca}^{2+}$ channel window along the voltage axis may have profound effects on basal and stimulated $\mathrm{Ca}^{2+}$ influx in VSMC, but also predict that shifts of the activation or inactivation curves of L-type
$\mathrm{Ca}^{2+}$ channels affect vasoconstriction and/or dilatation. For example, BAY K8644, which shifts the L-type $\mathrm{Ca}^{2+}$ channel activation curve to hyperpolarized potentials $[33,34]$, caused an increase of basal $\mathrm{Ca}^{2+}$ influx and tone (Figure 8, see also [30]). Furthermore, Bay K8644 shifted the $\left[\mathrm{K}^{+}\right]$-response curve to lower $\mathrm{K}^{+}$concentrations by about $8 \mathrm{mM}$ at midpoint, independent of the presence of levcromakalim, indicating that both the position of the window on the voltage axis and the resting membrane potential determine the window contraction.

Finally, because a number of alternatively spliced isoforms of the calcium channel gene protein exist, the Ltype $\mathrm{Ca}^{2+}$ channel population is not homogeneous. The isoforms display differences in tissue distribution, physiology, pharmacology and disease-related up- and/or down-regulation $[14,41,42,53]$, but also show altered voltage-dependent activation and inactivation, thereby influencing window currents [54]. Hence, changes in the expression of the channel isoforms within the vascular tree [55] as can occur in hypertension [53] or atherosclerosis [14] may affect the position of the L-type $\mathrm{Ca}^{2+}$ channel window along the voltage axis with effects on basal and stimulated $\mathrm{Ca}^{2+}$ influx and blood vessel tone. Moreover, different splice variants can be expressed within a single blood vessel type and depending on the dominance of one or more isoforms, this may determine the electrophysiological properties of the $\mathrm{Ca}^{2+}$ channels $[42,53,55,56]$.

\section{$\mathrm{K}^{+}$-induced $\mathrm{Ca}^{2+}$ sensitization}

The "window" intracellular $\mathrm{Ca}^{2+}$ signal elicited by depolarization reached a steady-state at $200 \mathrm{~s}$, whereas tension increased further at later time intervals. This pointed to a time-dependent and $\mathrm{Ca}^{2+}$-dependent $\mathrm{Ca}^{2+}$ sensitization, but after normalization of the contractile responses, there was no shift of the curves with time. Hence, the time-dependent $\mathrm{Ca}^{2+}$ sensitization was proportional to intracellular $\mathrm{Ca}^{2+}$, which is mainly determined by the extent of "steady-state" $\mathrm{Ca}^{2+}$ influx at each $\left[\mathrm{K}^{+}\right]$. This is in line with recent data indicating that the depolarization-induced $\mathrm{Ca}^{2+}$ sensitization depends on $\mathrm{Ca}^{2+}$ entry [15,18-21] and with the results obtained with the Rho kinase inhibitors Y-27632 and HA 1077. Rhokinase inhibition did not eliminate the bell-shape of the $\left[\mathrm{K}^{+}\right]$-force curves, but emphasized its voltage-dependence. Therefore, both continuous $\mathrm{Ca}^{2+}$ influx and $\mathrm{Ca}^{2+}$-dependent $\mathrm{Ca}^{2+}$ sensitization are necessary to maintain contraction, whereby $\mathrm{Ca}^{2+}$ influx occurs independently from $\mathrm{Ca}^{2+}$ sensitization, but not vice versa.

\section{Limitations of the study}

Voltage-clamp of multicellular aortic segments with electrophysiological techniques is impossible with current methods because of temporal and spatial voltage 
heterogeneity. Therefore, we clamped the aortic rings with extracellular $\mathrm{K}^{+}$although the resting $\mathrm{V}_{\mathrm{m}}$ is not solely determined by the $\mathrm{K}^{+}$equilibrium potential $\left(\mathrm{V}_{\mathrm{K}}\right)$, especially at low $\mathrm{K}^{+}$[51] (see Additional file 1). Taking into account that levcromakalim hyperpolarized $\mathrm{V}_{\mathrm{m}}$ of rat mesenteric arteries from -58 to $-82 \mathrm{mV}$ (hyperpolarization to $\mathrm{V}_{\mathrm{K}}$ ) [47] and that in the present study levcromakalim shifted the $\left[\mathrm{K}^{+}\right]$-force curve by $+5.9 \mathrm{mM} \mathrm{K}^{+}$at midpoint, $\mathrm{V}_{\mathrm{m}}$ at normal $\mathrm{K}^{+}$of $5.9 \mathrm{mM}$ was calculated to be $19 \mathrm{mV}$ less polarized than $\mathrm{V}_{\mathrm{K}}(-66 \mathrm{mV}$ instead of the Nernstian $-85 \mathrm{mV}$ ); this is in good agreement with resting $\mathrm{V}_{\mathrm{m}}$ of arterial SMCs mentioned in the literature $[28,47]$ (see Additional file 1). At 20 and $50 \mathrm{mM} \mathrm{K}^{+}$, the difference between $\mathrm{V}_{\mathrm{m}}$ and $\mathrm{V}_{\mathrm{K}}$ further diminished from 19 to 7 and $3 \mathrm{mV}$. Therefore, clamping the segments with $\mathrm{K}^{+}$was, in our hands, a good technique to restrain the resting $\mathrm{V}_{\mathrm{m}}$ of the SMCs.

\section{Conclusions}

Besides a phasic, fast transient $\mathrm{Ca}^{2+}$ and force component, depolarization of aortic segments of C57Bl6 mice with elevated extracellular $\mathrm{K}^{+}$causes a tonic, slow $\mathrm{Ca}^{2+}$ and force component. Both components reflect the electrophysiological properties of L-type $\mathrm{Ca}^{2+}$ channels. The tonic force component could be attributed to window Ltype $\mathrm{Ca}^{2+}$ influx, plays a prominent role in maintaining basal and stimulated intracellular $\mathrm{Ca}^{2+}$ and tension in mouse aorta, and together with Rho-kinase-mediated $\mathrm{Ca}^{2+}$ sensitizing may be of great importance for the (patho)physiology of conduit blood vessels. Hence, any modulation of L-type $\mathrm{Ca}^{2+}$ influx in VSMC is expected to affect endothelium-dependent and -independent $\mathrm{Ca}^{2+}$ mobilization and related vasomotor responses of blood vessels or arterial compliance. Window L-type $\mathrm{Ca}^{2+}$ influx may underlie the reduced relaxing efficacy of $\mathrm{NO}$ in mouse aorta when the contraction is elicited mainly via L-type $\mathrm{Ca}^{2+}$ influx [30]. Therefore, we conclude that every intervention (short or long term) that changes the resting $\mathrm{V}_{\mathrm{m}}$ of the VSMC or the expression/properties of the population of L-type $\mathrm{Ca}^{2+}$ channels, favoring one or another isoform, might have implications for the window $\mathrm{Ca}^{2+}$ current, influx and contraction, for the sensitivity to L-type $\mathrm{Ca}^{2+}$ channel blockers and $\mathrm{NO}$, for the arterial compliance and for the effects of hypertension on the cardiovascular system.

\section{Methods}

\section{Aortic segments}

The studies were approved by the Ethical Committee of the University of Antwerp, and the investigations conform to the Guide for the Care and Use of Laboratory Animals published by the US National Institutes of Health (NIH Publication No. 85-23, revised 1996). C57Bl6 mice $(n=72$, food and water ad libitum, 12/12 light-dark cycle) were used at the age of 4 to 7 months. Animals were euthanized under pentobarbital anesthesia (sodium pentobarbital, $75 \mathrm{mg} \mathrm{kg}$, i.p.). The thoracic aorta was carefully removed, stripped of adherent tissue and dissected systematically. Starting at the diaphragm, the ascending thoracic aorta was cut in segments of $2 \mathrm{~mm}$ width (5 to 6 segments). Vessels were immersed in Krebs Ringer solution $\left(\mathrm{KR} 37^{\circ} \mathrm{C}, 95 \% \mathrm{O}_{2} / 5 \% \mathrm{CO}_{2}, \mathrm{pH}\right.$ 7.4) with (in $\mathrm{mM}$ ): $\mathrm{NaCl} 118, \mathrm{KCl} 4.7, \mathrm{CaCl}_{2} 2.5$, $\mathrm{KH}_{2} \mathrm{PO}_{4}$ 1.2, $\mathrm{MgSO}_{4} 1.2, \mathrm{NaHCO}_{3}$ 25, CaEDTA 0.025, and glucose 11.1. When $\mathrm{Ca}^{2+}$ was omitted from the $\mathrm{KR}$, $1 \mathrm{mM}$ EGTA was added (further named $0 \mathrm{Ca}$ ) and, hence, to restore $2.5 \mathrm{mM}$ free $\mathrm{Ca}^{2+}, 3.5 \mathrm{mM} \mathrm{Ca}^{2+}$ was added to $0 \mathrm{Ca}$ (further named $0-3.5 \mathrm{Ca}$ ) from a $1.75 \mathrm{M}$ $\mathrm{CaCl}_{2}$ stock. High $\mathrm{K}^{+}$- solutions were prepared by replacing $\mathrm{NaCl}$ with equimolar $\mathrm{KCl}$.

To measure resting membrane potentials $\left(\mathrm{V}_{\mathrm{m}}\right)$ inverted (inside out) endothelium-denuded segments were mounted in the wire myograph, incubated with HEPES-buffered bathing solution $(5.4 \mathrm{mM} \mathrm{KCl,} 141 \mathrm{mM}$ $\mathrm{NaCl}, 10 \mathrm{mM}$ HEPES, $0.8 \mathrm{mM} \mathrm{MgCl}_{2}, 10 \mathrm{mM}$ glucose, $1.8 \mathrm{mM} \mathrm{CaCl}_{2}, 1 \mu \mathrm{M}$ amlodipine, $\mathrm{pH}=7.4$ at $37^{\circ} \mathrm{C}$ with $1 \mathrm{M} \mathrm{NaOH}$ ) and impaled with glass intracellular microelectrodes (filled with $2 \mathrm{mM} \mathrm{KCl}$ and tip resistances between 65 and $90 \mathrm{M} \Omega$ ). $\mathrm{V}_{\mathrm{m}}$ was measured with a HEKA EPC9 amplifier (HEKA Electroniks, Germany) in the zero current clamp mode and recorded on paper (Gould pen writer). Only measurements of $\mathrm{V}_{\mathrm{m}}$ starting with a sharp decrease of $\mathrm{V}_{\mathrm{m}}$ upon impalement and a sharp return to approximately $0 \mathrm{mV}$ upon withdrawal of the electrode were considered.

To simulate voltage clamp protocols used in electrophysiological studies, extracellular $\mathrm{K}^{+}$was used to clamp the aortic segments at certain estimated potentials. Depolarizing voltage steps were mimicked by graded elevation of extracellular $\mathrm{K}^{+}$starting from and returning to a normal resting potential at $5.9 \mathrm{mM} \mathrm{K}^{+}$(repetitive depolarization protocol). The holding potential from which voltage steps would be applied was mimicked by holding the segments at each $\mathrm{K}^{+}$concentration before a subsequent challenge with higher $\mathrm{K}^{+}$(cumulative depolarization protocol).

\section{Isometric tension measurements}

Aortic segments were mounted in $10 \mathrm{ml}$ organ baths, tension $(\mathrm{mN})$ was measured isometrically with a Statham UC2 force transducer (Gould) connected to a data acquisition system (Powerlab 8/30, ADInstruments, Spechbach, Germany) as described [30]. Segments were gradually stretched until a stable loading tension of 16 $\mathrm{mN}$, the optimal preload to attain maximal force development by 50 or $124 \mathrm{mM} \mathrm{K}^{+}$. Isometric force was reported in $\mathrm{mN}$. Nitric oxide $(\mathrm{NO})$ formation was inhibited with a combination of $300 \mu \mathrm{M} N^{\Omega}$-nitro-L-arginine 
methyl ester (L-NAME) and $300 \mu \mathrm{M} N^{\Omega}$-nitro-L-arginine (L-NNA) and to avoid any vasomotor interference due to prostanoids, $10 \mu \mathrm{M}$ indomethacin was present.

\section{Combined assay of isometric tension and VSMC $\mathrm{Ca}_{i}^{2+}$}

Segments were mounted in a wire $(40 \mu \mathrm{m})$ myograph above an inverted microscope (Axiovert 200, Carl Zeiss, Zaventem, Belgium) after removal of the endothelium by rubbing their interior with a braided silk wax to avoid interference by endothelial $\mathrm{Ca}^{2+}$ signals. Segments were loaded for 120 minutes with aerated $\left(95 \% \mathrm{O}_{2} / 5 \% \mathrm{CO}_{2}, \mathrm{pH}\right.$ 7.4) KR containing $10 \mu \mathrm{M}$ Fura-2 AM, $1 \mathrm{mg} / \mathrm{ml}$ bovine serum albumin and $0.02 \%$ Pluronic at room temperature. Then, temperature was raised to $37^{\circ} \mathrm{C}$ and the segment was set to its normalized diameter [30]. The single emission $(510 \mathrm{~nm})$ ratio at dual excitation $(340$ and $380 \mathrm{~nm})$ was used as a relative measure of free $\mathrm{Ca}_{\mathrm{i}}^{2+}$ (relative units, $\mathrm{RU})$ after subtraction of background emission values, which were determined by adding $2 \mathrm{mM} \mathrm{MnCl}{ }_{2}$ at the end of each experiment. Contractile force was measured simultaneously and reported in $\mathrm{mN} \mathrm{mm}^{-1}$ [30].

\section{Data analysis}

All results are expressed as mean \pm sem; $\mathrm{n}$ represents the number of mice. Time-force curves were fitted with a bi-exponential function revealing amplitudes and time constants of first (fast) and second (slow) components. Concentration-response curves were fitted with sigmoidal concentration-response equations with variable slope, which revealed maximal responses $\left(E_{\max }\right)$ and the negative logarithm of the concentration resulting in 50\% of the maximal effect $\left(\mathrm{pEC}_{50}\right)$ for each vessel segment. Two-way ANOVA with Bonferroni post-test (concentration-response curves) and paired or unpaired $t$-test (GraphPad Prism, version 5, GraphPad Software, San Diego California USA) were used to compare means of the different experimental groups. A 5\% level of significance was selected.

\section{Materials}

Sodium pentobarbital $\left(\mathrm{Nembutal}^{\circledR}\right)$ was obtained from Sanofi (Brussels, Belgium), indomethacin from CERTA (Belgium), L-NNA, L-NAME, nifedipine, ryanodine, 2APB, HA-1077 dihydrochloride from Sigma (Bornem, Belgium), Fura 2-AM from Molecular Probes (Invitrogen, Merelbeke, Belgium), ( \pm ) BAY K8644, levcromakalim, glibenclamide from TOCRIS (Bristol, United Kingdom), Y-27632 dihydrochloride from Abcam Biochemicals (Cambridge, UK).

\section{Additional file}

Additional file 1: Additional information.

\section{Abbreviations}

$\mathrm{Ca}^{2+}$ : Calcium; VSMC: Vascular smooth muscle cell; $\mathrm{K}^{+}$: Potassium; 2-APB: 2-aminoethoxydiphenyl borate; L-NAME: $N^{\Omega}$-nitro-L-arginine methyl ester; L-NNA: $N^{2}$-nitro-L-arginine; NO: Nitric oxide; SERCA: Sarco-endoplasmic reticulum calcium ATPase; SR: Sarcoplasmic reticulum; eNOS: Endothelial nitric oxide synthase; $V_{K}$ : Equilibrium potential for $K^{+}$ions; $V_{m}$ : Membrane potential.

\section{Competing interests}

The authors declare that they have no competing interests.

\section{Authors' contributions}

All authors read and approved the final manuscript. PF and $\mathrm{CVH}$ conceived of the study, designed the experiments, collected and analyzed the data; PF and $\mathrm{HB}$ drafted the manuscript, PF, CVH, JVL, DS, WM, GDM and HB

participated in interpretation of the results and final draft of the manuscript.

\section{Acknowledgements}

This work was supported by grants from the Research Foundation - Flanders (Fonds voor Wetenschappelijk Onderzoek, FWO, Vlaamse Gemeenschap, project G.0174.06 and G.0293.10 N). Johanna Van Langen is supported by a Ph. D. fellowship (Aspirant) of the FWO-Flanders. With special thanks to Francois Pittoors and Pierre-Paul Van Bogaert (Faculty of Medicine, Department Physiology, University of Antwerp) for help with electrophysiological measurements.

\section{Author details}

${ }^{1}$ Laboratory of Physiopharmacology, University of Antwerp, Universiteitsplein 1 Building T, 2.18, Wilrijk B-2610, Belgium. ' ${ }^{2}$ aboratories of Pharmacology,

University of Antwerp, Antwerp, Belgium.

Received: 30 March 2012 Accepted: 28 August 2012

Published: 3 September 2012

\section{References}

1. Moosmang S, Schulla V, Welling A, Feil R, Feil S, Wegener JW, Hofmann F, Klugbauer N: Dominant role of smooth muscle L-type calcium channel $\mathrm{Ca}_{\mathrm{v}} 1.2$ for blood pressure regulation. EMBO J 2003, 22:6027-6034.

2. Pesic A, Madden JA, Pesic M, Rusch NJ: High blood pressure upregulates arterial L-type $\mathrm{Ca}^{2+}$ channels: is membrane depolarization the signal? Circ Res 2004, 94:e97-e104.

3. Rhee SW, Stimers JR, Wang W, Pang L: Vascular smooth muscle-specific knockdown of the noncardiac form of the L-type calcium channel by microRNA-based short hairpin RNA as a potential antihypertensive therapy. J Pharmacol Exp Ther 2009, 329:775-782.

4. Zhou ZH, Wang J, Xiao H, Chen ZJ, Wang M, Cheng X, Liao YH: A novel autoantibody in patients with primary hypertension: antibody against L-type Ca ${ }^{2+}$ channel. Chin Med J (Engl) 2008, 121:1513-1517.

5. Mancia G, De BG, Dominiczak A, Cifkova R, Fagard R, Germano G, Grassi G, Heagerty AM, Kjeldsen SE, Laurent S, et al: 2007 Guidelines for the Management of Arterial Hypertension: The Task Force for the Management of Arterial Hypertension of the European Society of Hypertension (ESH) and of the European Society of Cardiology (ESC). $J$ Hypertens 2007, 25:1105-1187.

6. Westerhof N, Lankhaar JW, Westerhof BE: The arterial Windkessel. Med Biol Eng Comput 2009, 47:131-141.

7. Mitchell GF: Pulse pressure, arterial compliance and cardiovascular morbidity and mortality. Curr Opin Nephrol Hypertens 1999, 8:335-342.

8. Belz GG: Elastic properties and Windkessel function of the human aorta. Cardiovasc Drugs Ther 1995, 9:73-83.

9. Bellien J, Favre J, lacob M, Gao J, Thuillez C, Richard V, Joannides R: Arterial stiffness is regulated by nitric oxide and endothelium-derived hyperpolarizing factor during changes in blood flow in humans. Hypertension 2010, 55:674-680.

10. Safar ME, Pannier B, Laurent S, London GM: Calcium-entry blockers and arterial compliance in hypertension. J Cardiovasc Pharmacol 1989, 14(Suppl 10):S1-S6.

11. Slama M, Safavian A, Tual JL, Laurent S, Safar ME: Effects of antihypertensive drugs on large artery compliance. Neth J Med 1995, 47:162-168. 
12. Essalihi R, Zandvliet ML, Moreau S, Gilbert LA, Bouvet C, Lenoel C, Nekka F, McKee MD, Moreau P: Distinct effects of amlodipine treatment on vascular elastocalcinosis and stiffness in a rat model of isolated systolic hypertension. J Hypertens 2007, 25:1879-1886.

13. Vayssettes-Courchay C, Ragonnet C, Isabelle M, Verbeuren TJ: Aortic stiffness in vivo in hypertensive rat via echo-tracking: analysis of the pulsatile distension waveform. Am J Physiol Heart Circ Physiol 2011, 301:H382-H390.

14. Tiwari S, Zhang Y, Heller J, Abernethy DR, Soldatov NM: Atherosclerosisrelated molecular alteration of the human Cav1.2 calcium channel alpha1C subunit. Proc Natl Acad Sci USA 2006, 103:17024-17029.

15. Ratz PH, Miner AS: Role of protein kinase Czeta and calcium entry in $\mathrm{KCl}$-induced vascular smooth muscle calcium sensitization and feedback control of cellular calcium levels. J Pharmacol Exp Ther 2009, 328:399-408.

16. Fernandez-Tenorio M, Porras-Gonzalez C, Castellano A, del Valle-Rodriguez A, Lopez-Barneo J, Urena J: Metabotropic regulation of RhoA/Rhoassociated kinase by L-type Ca2+ channels: new mechanism for depolarization-evoked mammalian arterial contraction. Circ Res 2011, 108:1348-1357.

17. Van Assche T, Fransen P, Guns PJ, Herman AG, Bult H: Altered $\mathrm{Ca}^{2+}$ handling of smooth muscle cells in aorta of apolipoprotein E-deficient mice before development of atherosclerotic lesions. Cell Calcium 2007, 41:295-302

18. Villalba N, Stankevicius $E$, Simonsen U, Prieto D: Rho kinase is involved in $\mathrm{Ca}^{2+}$ entry of rat penile small arteries. Am J Physiol Heart Circ Physiol 2008, 294:H1923-H1932.

19. Sakurada S, Takuwa N, Sugimoto N, Wang Y, Seto M, Sasaki Y, Takuwa Y: $\mathrm{Ca}^{2+}$-dependent activation of Rho and Rho kinase in membrane depolarization-induced and receptor stimulation-induced vascular smooth muscle contraction. Circ Res 2003, 93:548-556.

20. Hirano $\mathrm{K}$ : Current topics in the regulatory mechanism underlying the $\mathrm{Ca}^{2+}$ sensitization of the contractile apparatus in vascular smooth muscle. J Pharmacol Sci 2007, 104:109-115.

21. Mita M, Yanagihara H, Hishinuma S, Saito M, Walsh MP: Membrane depolarization-induced contraction of rat caudal arterial smooth muscle involves Rho-associated kinase. Biochem J 2002, 364:431-440.

22. Ganitkevich $V Y$, Isenberg G: Contribution of two types of calcium channels to membrane conductance of single myocytes from guinea-pig coronary artery. J Physiol 1990, 426:19-42.

23. Matsuda JJ, Volk KA, Shibata EF: Calcium currents in isolated rabbit coronary arterial smooth muscle myocytes. J Physiol 1990, 427:657-680.

24. Fleischmann BK, Murray RK, Kotlikoff MI: Voltage window for sustained elevation of cytosolic calcium in smooth muscle cells. Proc Natl Acad Sci US A 1994, 91:11914-11918.

25. Curtis TM, Scholfield CN: Nifedipine blocks $\mathrm{Ca}^{2+}$ store refilling through a pathway not involving L-type $\mathrm{Ca}^{2+}$ channels in rabbit arteriolar smooth muscle. J Physiol 2001, 532:609-623.

26. Smirnov SV, Aaronson PI: $\mathrm{Ca}^{2+}$ currents in single myocytes from human mesenteric arteries: evidence for a physiological role of L-type channels. J Physiol 1992, 457:455-475.

27. Zhang J, Berra-Romani R, Sinnegger-Brauns MJ, Striessnig J, Blaustein MP Matteson DR: Role of $\mathrm{Ca}_{\mathrm{v}} 1.2 \mathrm{~L}$-type $\mathrm{Ca}^{2+}$ channels in vascular tone: effects of nifedipine and $\mathrm{Mg}^{2+}$. Am J Physiol Heart Circ Physiol 2007, 292: $\mathrm{H} 415-\mathrm{H} 425$

28. Cobine CA, Callaghan BP, Keef KD: Role of L-type calcium channels and $\mathrm{PKC}$ in active tone development in rabbit coronary artery. Am J Physiol Heart Circ Physiol 2007, 292:H3079-H3088.

29. Sonkusare S, Palade PT, Marsh JD, Telemaque S, Pesic A, Rusch NJ: Vascular calcium channels and high blood pressure: pathophysiology and therapeutic implications. Vascul Pharmacol 2006, 44:131-142.

30. Van Hove $C E$, Van der Donckt $C$, Herman AG, Bult $H$, Fransen P: Vasodilator efficacy of nitric oxide depends on mechanisms of intracellular calcium mobilization in mouse aortic smooth muscle cells. Br J Pharmacol 2009, 158:920-930.

31. Bootman MD, Collins TJ, Mackenzie L, Roderick HL, Berridge MJ, Peppiatt CM: 2-aminoethoxydiphenyl borate (2-APB) is a reliable blocker of store-operated $\mathrm{Ca}^{2+}$ entry but an inconsistent inhibitor of Ins $\mathrm{P}^{3}$-induced $\mathrm{Ca}^{2+}$ release. FASEB J 2002, 16:1145-1150.
32. Barrett CF, Cao YQ, Tsien RW: Gating deficiency in a familial hemiplegic migraine type 1 mutant P/Q-type calcium channel. J Biol Chem 2005, 280:24064-24071.

33. Saponara S, Sgaragli G, Fusi F: Quercetin antagonism of Bay K 8644 effects on rat tail artery L-type $\mathrm{Ca}(2+)$ channels. Eur J Pharmacol 2008, 598:75-80.

34. Teramoto $\mathrm{N}$, Tomoda T, Ito $\mathrm{Y}$ : Mefenamic acid as a novel activator of L-type voltage-dependent $\mathrm{Ca}^{2+}$ channels in smooth muscle cells from pig proximal urethra. Br J Pharmacol 2005, 144:919-925.

35. Edwards G, Dora KA, Gardener MJ, Garland CJ, Weston AH: $\mathrm{K}^{+}$is an endothelium-derived hyperpolarizing factor in rat arteries. Nature 1998, 396:269-272.

36. Edwards G, Weston AH: Potassium and potassium clouds in endotheliumdependent hyperpolarizations. Pharmacol Res 2004, 49:535-541.

37. Karaki H, Ozaki H, Hori M, Mitsui-Saito M, Amano K, Harada K, Miyamoto S, Nakazawa H, Won KJ, Sato K: Calcium movements, distribution, and functions in smooth muscle. Pharmacol Rev 1997, 49:157-230.

38. Urena J, del Valle-Rodriguez A, Lopez-Barneo J: Metabotropic $\mathrm{Ca}^{2+}$ channel-induced calcium release in vascular smooth muscle. Cell Calcium 2007, 42:513-520.

39. Akata T: Cellular and molecular mechanisms regulating vascular tone. Part 1: basic mechanisms controlling cytosolic $\mathrm{Ca}^{2+}$ concentration and the $\mathrm{Ca}^{2+}$-dependent regulation of vascular tone. J Anesth 2007, 21:220-231.

40. Navedo MF, Amberg GC, Westenbroek RE, Sinnegger-Brauns MJ, Catterall WA, Striessnig J, Santana LF: Ca(v)1.3 channels produce persistent calcium sparklets, but $\mathrm{Ca}(\mathrm{v}) 1.2$ channels are responsible for sparklets in mouse arterial smooth muscle. Am J Physiol Heart Circ Physiol 2007, 293:H1359-H1370.

41. Liao P, Yong TF, Liang MC, Yue DT, Soong TW: Splicing for alternative structures of $\mathrm{Ca}_{\mathrm{v}} 1.2 \mathrm{Ca}^{2+}$ channels in cardiac and smooth muscles. Cardiovasc Res 2005, 68:197-203.

42. Liao P, Yu D, Li G, Yong TF, Soon JL, Chua YL, Soong TW: A smooth muscle $\mathrm{Ca}_{\mathrm{v}} 1.2$ calcium channel splice variant underlies hyperpolarized window current and enhanced state-dependent inhibition by nifedipine. J Biol Chem 2007, 282:35133-35142.

43. Nieves-Cintron M, Amberg GC, Navedo MF, Molkentin JD, Santana LF: The control of $\mathrm{Ca}^{2+}$ influx and NFATC3 signaling in arterial smooth muscle during hypertension. Proc Natl Acad Sci U S A 2008, 105:15623-15628.

44. McNeish AJ, Altayo FJ, Garland CJ: Evidence both L-type and non-L-type voltage-dependent calcium channels contribute to cerebral artery vasospasm following loss of NO in the rat. Vascul Pharmacol 2010, 53:151-159.

45. Chataigneau T, Feletou M, Huang PL, Fishman MC, Duhault J, Vanhoutte PM: Acetylcholine-induced relaxation in blood vessels from endothelial nitric oxide synthase knockout mice. Br J Pharmacol 1999, 126:219-226.

46. Dietrich A, Mederos YS, Gollasch M, Gross V, Storch U, Dubrovska G, Obst M, Yildirim E, Salanova B, Kalwa H, et al: Increased vascular smooth muscle contractility in TRPC6 ${ }^{-1-}$ mice. Mol Cell Biol 2005, 25:6980-6989.

47. Weston AH, Richards GR, Burnham MP, Feletou M, Vanhoutte PM, Edwards $\mathrm{G}: \mathrm{K}^{+}$-induced hyperpolarization in rat mesenteric artery: identification, localization and role of $\mathrm{Na}^{+} / \mathrm{K}^{+}$-ATPases. Br J Pharmacol 2002, 136:918-926.

48. Feletou M, Vanhoutte PM: EDHF: an update. Clin Sci (Lond) 2009, 117:139-155.

49. Scotland RS, Madhani M, Chauhan S, Moncada S, Andresen J, Nilsson H, Hobbs AJ, Ahluwalia A: Investigation of vascular responses in endothelia nitric oxide synthase/cyclooxygenase-1 double-knockout mice: key role for endothelium-derived hyperpolarizing factor in the regulation of blood pressure in vivo. Circulation 2005, 111:796-803.

50. Safar ME, Blacher J, Jankowski P: Arterial stiffness, pulse pressure, and cardiovascular disease-is it possible to break the vicious circle? Atherosclerosis 2011, 218:263-271.

51. Knot HJ, Nelson MT: Regulation of arterial diameter and wall $\left[\mathrm{Ca}^{2+}\right]$ in cerebral arteries of rat by membrane potential and intravascular pressure. J Physiol 1998, 508(Pt 1):199-209.

52. Morel N, Godfraind T: Selective interaction of the calcium antagonist amlodipine with calcium channels in arteries of spontaneously hypertensive rats. J Cardiovasc Pharmacol 1994, 24:524-533.

53. Tang ZZ, Liao P, Li G, Jiang FL, Yu D, Hong X, Yong TF, Tan G, Lu S, Wang J, et al: Differential splicing patterns of L-type calcium channel $\mathrm{Ca}_{\mathrm{v}} 1.2$ 
subunit in hearts of Spontaneously Hypertensive Rats and Wistar Kyoto Rats. Biochim Biophys Acta 2008, 1783:118-130.

54. Liao P, Yu D, Lu S, Tang Z, Liang MC, Zeng S, Lin W, Soong TW: Smooth muscle-selective alternatively spliced exon generates functional variation in Cav1.2 calcium channels. J Biol Chem 2004, 279:50329-50335.

55. Nystoriak MA, Murakami K, Penar PL, Wellman GC: Ca(v)1.2 splice variant with exon $9^{*}$ is critical for regulation of cerebral artery diameter. Am J Physiol Heart Circ Physiol 2009, 297:H1820-H1828.

56. Cheng X, Pachuau J, Blaskova E, suncion-Chin M, Liu J, Dopico AM, Jaggar $\mathrm{JH}$ : Alternative splicing of $\mathrm{Ca}_{\mathrm{v}} 1.2$ channel exons in smooth muscle cells of resistance-size arteries generates currents with unique electrophysiological properties. Am J Physiol Heart Circ Physiol 2009, 297:H680-H688.

doi:10.1186/1472-6793-12-9

Cite this article as: Fransen et al:: Contribution of transient and sustained calcium influx, and sensitization to depolarization-induced contractions of the intact mouse aorta. BMC Physiology 2012 12:9.

\section{Submit your next manuscript to BioMed Central and take full advantage of:}

- Convenient online submission

- Thorough peer review

- No space constraints or color figure charges

- Immediate publication on acceptance

- Inclusion in PubMed, CAS, Scopus and Google Scholar

- Research which is freely available for redistribution 